\title{
Ethnobotanical Study of Some Medicinal Species Used in Kimvula City (Kongo Central/ RDC)
}

\author{
L. K. Lassa \\ G. B. Ilumbe \\ Department of Biology, Faculty of Sciences, University of Kinshasa, \\ DR Congo (Laboratoire de botanique systématique et d'écologie végétale) \\ A. M. Biloso \\ Department of Rural Economy, Faculty of Agriculture Sciences, \\ University of Kinshasa, DR Congo \\ D. M. Y. Masens \\ JP. M. Habari \\ F. L. Lukoki \\ Department of Biology, Faculty of Sciences, University of Kinshasa, \\ DR Congo (Laboratoire de botanique systématique et d'écologie végétale)
}

Doi:10.19044/esj.2021.v17n10p345

Submitted: 20 July 2020

Accepted: 15 March 2021

Published: 31 March 2021
Copyright 2021 Author(s)

Under Creative Commons BY-NC-ND

4.0 OPEN ACCESS

Cite As:

Lassa L. K., Ilumbe G. B., Biloso A. M., Masens D. M. Y.,Habari JP. M. \& Lukoki F. L. (2021). Ethnobotanical Study of Some Medicinal Species Used in Kimvula City (Kongo Central/ RDC). European Scientific Journal, ESJ, 17(10), 345.

https://doi.org/10.19044/esj.2021.v17n10p345

\begin{abstract}
This study has been conducted at Kimvula city. The goal was to investigate the medicinal plants used in that city. Thus, any ethnobotanical survey has been realized on the use of the plants in six towns by direct interviews among 180 peoples with an average of age comprise between 1770 years old with high representatives of women. This study has allowed us to establish a floristic list of 188 medicinal species belonging in 158 genera and 69 families where Fabaceae dominant group. Anemia was indications mostly cited as a sickness threated by using plants. Concerning the characteristics of the treatment preparation, leaves are the plant's organs mostly used; decoction is the preparation way cited and the oral admistration is the administration way for those medicinal drugs. Morinda morindoides, Ocimum gratissimum,
\end{abstract}


Disphania ambrosiö̈des and Moringa oleifera have the VAUs superior or eaual to 1.10. There is not a link concerning the use of plants between the inhabitant of group 1 and the inhabitant of group 2. By the wah, that there is a link concerning the use of plants between the Lona, Winda, Pado, Revolution and Kinata neighborhoods (Group 2). Three sspcies characterized the group 1 like: Clematis hirsuta, Saccharum officinarum and Voacanga africana, and four especies Ceiba pentandra, Indigofera paracapitata, Maprounea africana and Ochna afzelii characterized the group 2.

Keywords: Medicinal plants, ethnobotanic, threated sickness, Kimvula city, DR Congo

\section{Introduction}

Medicinal plants constitute a precious resource for a hug majority of rural population in Africa, where more than $80 \%$ use it to assure health care (OMS, 2004; Jiofack et al., 2009, 2010; Dibong et al., 2014; Sylla et al., 2018; Ngbolua et al., 2019). The natural resources of traditional medicine are very diverse; this medicine draws minerals, animals and especially plants, the remedies necessary to restore the patient's health (Ould Mohamed et al., 2009; Caroline G., 2013; Nzuki, 2016; Intissar A.O., 2016).

For a long time, the use of plants has enabled the various cultures of the world to guarantee to a large extent the health of their populations (Bastien, 1987a; Milliken et al., 1992; Geissler et al., 2002; Milliken and Albert, 1997; Milliken, 1997a; Heinrich et al., 1998b; Alexiades, 1999; Bennett et al., 2000; Leonti et al., 2002; Casagrande, 2002; Voeks, 2004). WHO (2002) and Augereau (2008) estimate that approximately less than half of the population in developing countries has regular access to essential medicines. According to Kerharo et al. (1974), WHO (1983), OAU (1985), Sofowora (1996), WHO (2002) and Augereau (2008), 75 to $80 \%$ of the populations of the countries of the dependent African countries linked to traditional medicine and more than those preparations based on local medicinal plants. Likewise, Adjanohoun (1993) points out that in rural areas where health facilities are often lacking, the population is $100 \%$ dependent on medicinal plants. As Balée (1994) points out, Phillips et al. (1994), Augereau (2008) and Ilumbe (2010), the use of plants varies from one ethnic group to another, because a plant perceived as of great use by an ethnic group can be considered useless by another group (Ilumbe, 2014).

Admittedly, various ethnobotanical studies have been carried out in the different ethnic groups of the different provinces of DR Congo such as Lingola (2001), Masiala (2002), Toirambe (2002), Lumbu (2005), Makumbelo et al. (2008 and 2018), Ilumbe (2006, 2010), Magilu (2007), Gafuene (2009), Bikandu (2007), Bikandu et al. (2018), Lassa (2007, 2012), Mato (2005) and 
Musuyu (2006). Some ethnobotanical studies have been carried out in the province of central Kongo, such as those of Kimbungu (2003), Lathan (2007) and Lukoki (2011), on the other hand very few studies or nothing at all have been done on ethnobotanical surveys in the city of Kimvula.

In this study, the working hypotheses have been summarized as follows: "traditional folk medicine constitutes one of the poles of ethnobotanical knowledge; the people of the city of Kimvula use the same plants to cure diseases, they use the same organs, they use the same methods of preparation and administration and they form the same community in the use of medicinal plants."

During this study, the main objective to contribute of the knowledge about plants using as medicinal species in Kimvula. To achieve this objective, surveys were carried out with local informants to find out which medicinal plants are used by local populations to enhance their value.

To achieve this overall objective, we have set ourselves the following specific objectives:

- Conduct ethnobotanical surveys on medicinal plants in the city of Kimvula;

- Give the general characteristics of the recipes;

- Group all the districts (Kinata, Lona, Mvula nlondi, Pado, Revolution and Winda) using a hierarchical ascending classification method (CHA) to check if all the districts use the same plants,

- Assess the cultural significance of the medicinal plants in the city of Kimvula.

\section{Area, Material and Methods}

\subsection{Study Area}

The city of Kimvula is located in the Guinean-Congolese and Zambian transition zone of White (1980) or the Sudano-Zambian region dominated by clear forests and savannas, according to Lebrun (1947).

The geographic coordinates are $5^{\circ} 42$ 'to $5^{\circ} 44^{\prime}$ South; $15^{\circ} 57^{\prime}$ 's to $15^{\circ} 59^{\prime}$ 's East; 561 to $567 \mathrm{~m}$ above sea level (Anonymous, 2002). This altitude contrasts with the $920 \mathrm{~m}$ altitude of Kingoma in the north-west and the 650 to $785 \mathrm{~m}$ altitude of the Lubisi sector in the south-east (Figure 1).

The city of Kimvula is located $165 \mathrm{~km}$ (as the crow flies) southeast of the city of Kinshasa (Encarta, 2005). At the level of the village Kinzala on the road axis (national no. 16) connecting Kimvula to Kisantu is the limit separating the territory of Kimvula from the territory of Madimba to the West.

The Kimvula region enjoys an Aw4 type climate according to the Köppen classification. There is a rainy season that lasts 8 months, from midSeptember to mid-May and a dry season of 4 months from mid-May to midSeptember. Figure 1 shows a view of the city of Kimvula. 

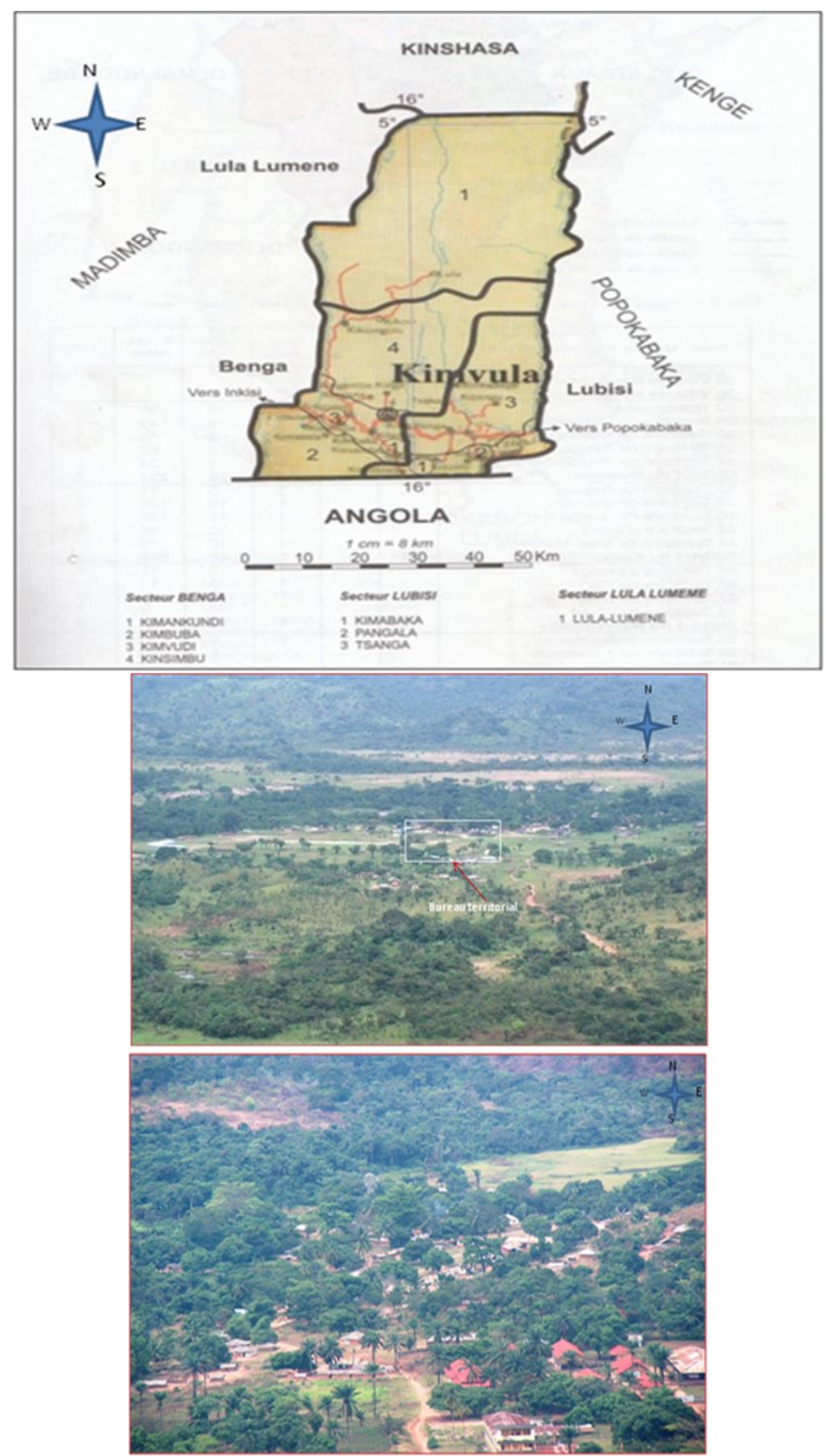

Figure 1: Location of the City of Kimvula in a deep valley between several hills (a) and City of Kimvula, Revolution district where we see in the foreground the general hospital and the convent of the sisters with red sheet metal roof $(b)$ 


\subsection{Material}

The biological material that was used in this study consists of samples of plants collected in the City of Kimvula. So these are the parts of the plants (root, stem, bark, sap, rhizome, flower bud, leaf, resin, whole plant, fruit, seed ...). Harvesting the plants at the city of Kimvula required the following equipment: Digital camera (Canon Power Shot A720 IS), field notebook, pen, pencil, press, herbarium paper, cardboard and harvesting knife.

\subsection{Methods}

The preparation of a reference herbarium is a necessary basis for any study of botanical inventory. The plants were harvested in the city of Kimvula to constitute a herbarium. For a correct determination of the plants, the flora of the Belgian Congo and the main floristic works of the neighboring countries of Central Africa: Flora of Gabon, Flora of Central Africa and Flora of Cameroon were used.

The verification of determinations was made by comparison with the specimens kept at the Herbarium of Kinshasa "IUK" at the University of Kinshasa, in the Department of Biology.

Some traditional healers but also some young girls and boys who inherited some knowledge generally from their parents on the use of medicinal plants in the city of Kimvula, are among those interviewed.

The present study was carried out from a series of ethnobotanical surveys using semi-structured interview using a pre-developed questionnaire, and the information sought concerned the plants they use to treat diseases, the organs of the plant used, the method of preparation of the recipes and the method of administration (Martin, 1995; Kalanda et al., 1995; Ilumbe, 2014; Alexiades, 1996; Zerbo et al., 2007). Questions were asked in local languages, Lingala and Kikongo. A total of 180 people were interviewed between the ages of 17 and 72 . Data processing began by entering the plant lists by neighborhood and by interview, followed by the encoding of various general characteristics of the recipes. Then, the data were processed using the software: MS Word, Excel and MVSP.

To better interpret the medicinal cultural value of plants, the Use Agreement Value Index (VAUs) (Ilumbe, 2010 and 2014) which combines the Use Value Index (VUs) (Philips et al. , 1993) and the confirmation index proposed by Byg and Balslev (2001) was used.

$$
\text { VAUs }=\text { VUs } \times \text { ICs }
$$

The usage value index VUs is expressed by:

$$
\text { VUs }=\frac{\sum_{i=1}^{n} \text { Uis }}{n s}
$$


Where VUs equals the number of uses of the species s mentioned by the informant $i$ and ns equals the number of people who cited this species.

One technique that takes into account the consensus of participants and can thus be used to assess the cultural importance of plants is the proportion of informant agreement (Trotter et al. And Logan, 1986; Thomas et al., 2009). For the present study, the original formula proposed by Byg and Balslev (2001) has been interpreted to express the consensus of informants or confirmation index of medicinal plants. Thus, the consensus of informants is calculated as follows:

$$
\mathrm{ICs}=\frac{\mathrm{Na}}{N t}
$$

Where ICs is the confirmation index, $\mathrm{Na}=$ number of people who cited this species and $\mathrm{Nt}=$ total number of people interviewed.

For the determination of groupings and ordination, the hypothesis that the users of medicinal plants living in the city of Kimvula form the same community in the use of plants in traditional medicine will be verified; an obtained similarity matrix from the Jaccard similarity coefficient will be used to build hierarchies for the classification of surveys or informants by district for this case. The different uses of plants can be made between neighborhoods in general, depending on the presence / absence of plants using the similarity measure. Thus, the calculation of a similarity coefficient makes it possible to quantify the degree of association of two species, or even the level of similarity between the districts taking into account their floristic composition, for example (Kent and Coker, 1996; Legendre and Legendre, 1998; Stokes et al., 2000; Magurran, 2004). Thus, the chosen Jaccard index focuses on the double presences(a), that is to say on the plants observed as used by the successive districts. The maximum similarity is equal to 1,0 being the minimum value. The visualization of the content of these matrices is done in the form of dendrograms.

\section{Results and Discussions}

\subsection{Floral Composition}

To better understand the medicinal floral of the city of Kimvula on a botanical level, a list of plant species has been drawn up from ethnobotanical surveys. And then an arrangement of families and genera represented in this floral was made. In total, 188 species used as medicinal plants have an inventory was built in the six neighborhoods surveyed in the city of Kimvula, these are divided into 158 genera and 69 families. The distribution of genera and species in botanical families is given in Table 2. The botanical identification showed that among the 69 families identified, the most 
represented are the Fabaceae 17 genera (10.76\%) and 22 species (11. 70\%), the Rubiaceae 10 genera (6.33\%) and 11 species (5.85\%), the Euphorbiaceae 10 genera (6.33\%) and 10 species $(5.32 \%)$, the Malvaceae 9 genera $(5.70 \%)$ and 9 species (4.79\%) and the Asteraceae 8 genera (5.06\%) and 8 species (4.26\%). Betti (2001) in the markets of Yaoundé, Souâda et al. (2007) in the region of Rabat and Paulin et al. (2006) in the Niangoloko classified forest in Burkina Faso also confirm the predominance of the Fabaceae family in their investigations.

\subsubsection{Distribution of species in botanical families}

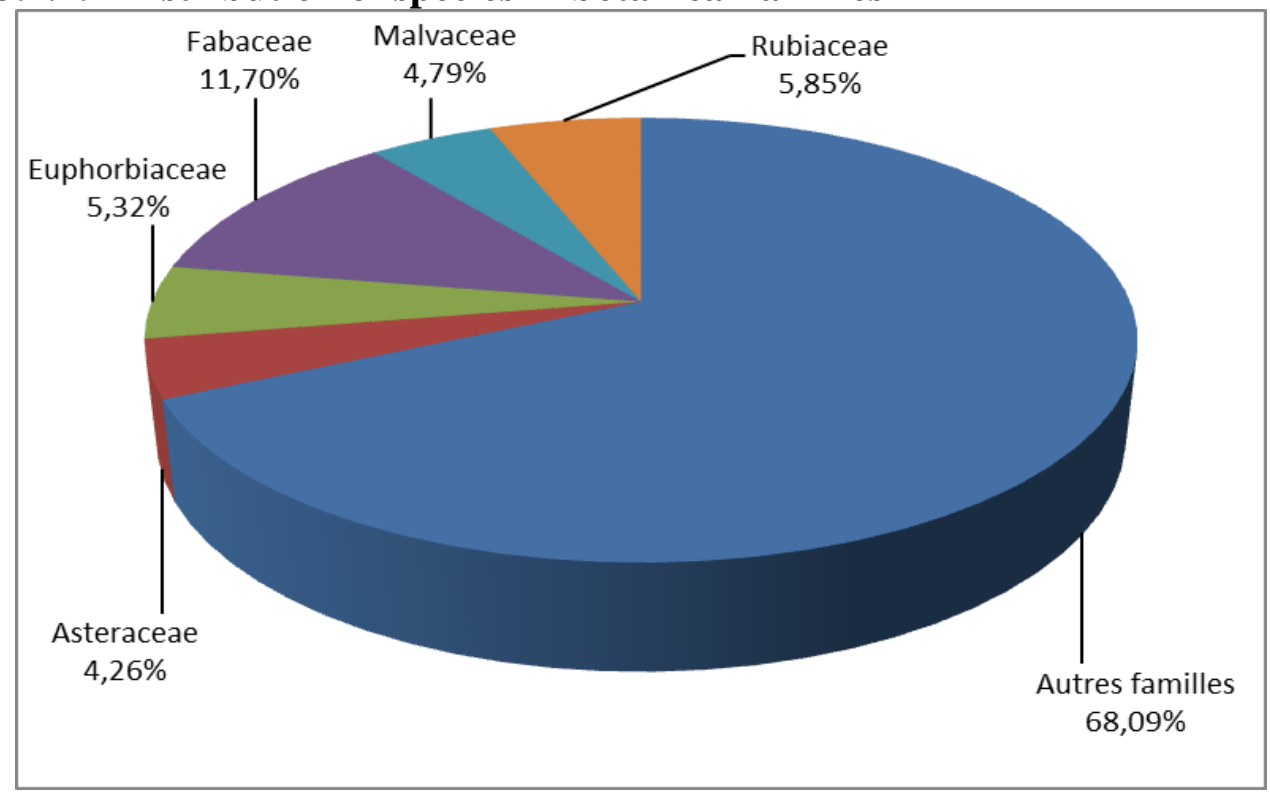

Figure 2: distribution of species in botanical families

\subsection{Interviewed People}

A total of 180 people were interviewed during this study in 6 neighborhoods in the city of Kimvula (Table 2). Overall, there are 47 men and 133 women. Table 2 reveals the low participation of men in the use of medicinal plants, especially in the Kinata, Lona, Mvula nlondi and Révolution districts. 


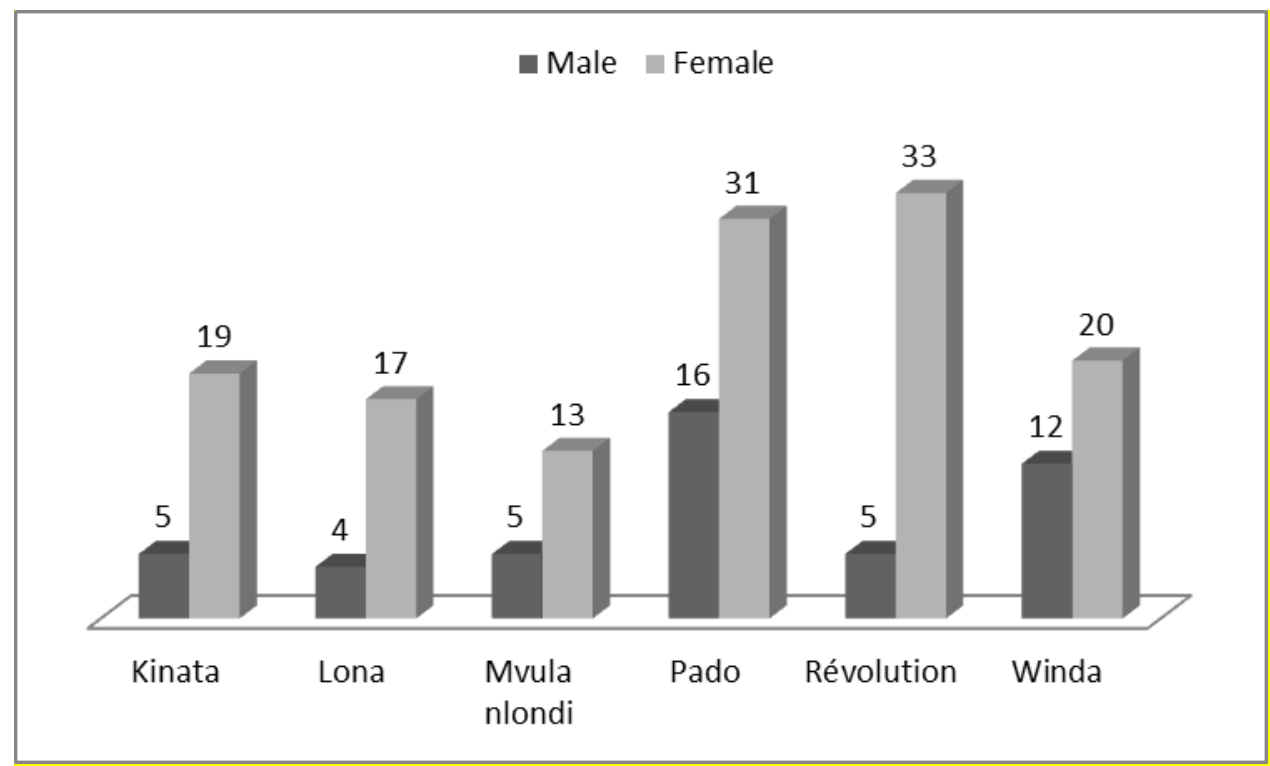

Figure 3: Number of people interviewed on medicinal plants in the city of Kimvula

\subsection{Ethnobotanical and Pharmacological Aspects}

\subsubsection{Ailments Treated by Medicinal Plants}

A better understanding of the traditional treatments practiced in the city of Kimvula has made it possible to list around a hundred diseases treated by medicinal plants. The results obtained show that most plants are involved in the treatment of anemia (11.81\%), cough (11.39\%), fever $(10.27 \%)$, stomach aches $(7.64 \%)$, spleen disorders $(6.24 \%)$, general pain $(5.26 \%)$, back pain $(4.37 \%)$ and malaria (4.01\%) (Figure 4$)$.

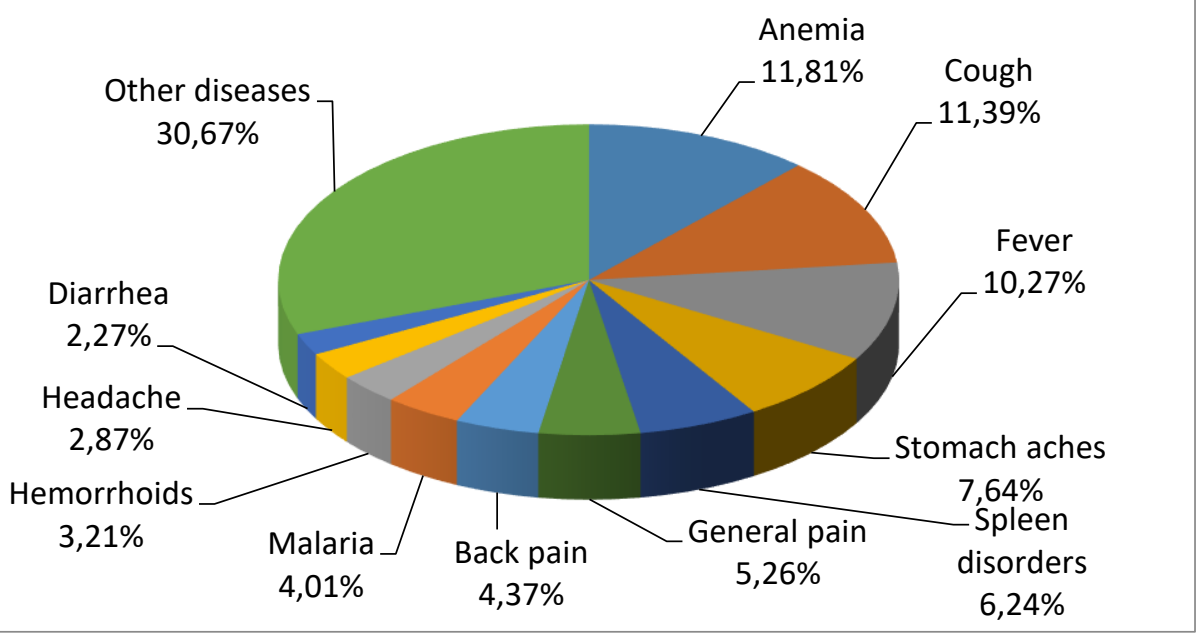

Figure 4: Main disease well-groomed in Kimvula city 


\subsubsection{Vegetable organs used in recipes}

The preparation of phytotherapeutic recipes involves 31 plant organs often used in herbal medicine in the city of Kimvula when the plant is not fully used. The leaf is the organ most used with 3298 citations (59.82\%) followedy the root with 813 citations (14.75\%), the stem bark with 385 citations (6.98\%) and the seed with 338 citations $(6.13 \%)$. The other organs have little interest (Figure 3).

Ilumbe (2006, 2010 and 2014), Wome (1985), Mabika (1983), Benlamdini et al. (2014), Mato (2005), Magilu (2006 and 2007), Dibong et al. (2011), Fézan et al. (2008), Koffi et al. (2009), Ould (2009), Souad et al. (2010), Bitsindou (1996), Kawukpa and Angoyo (1994) also note the frequent use of the leaves in traditional remedies. For Musuyu (2006), Lubini (1990) and Bitsindou (1996), on the other hand, the barks are the most used organ in the preparation of recipes. As for Lassa (2012), the roots constitute the first organ most used in the preparation of different recipes.

As reported by Bitsindou (1996) and Ilumbe (2010), the importance of the uses of the leaves and stem bark could be explained by the fact that they are generally the seat of biosynthesis and sometimes the storage of metabolites secondary responsible for the biological properties of the plant. Diafouka (1997) argues that the importance of the bark is often due to the ease of harvesting. However, the species for which the leaves are used are less vulnerable than those for which the bark of stems and / or roots is used. It is desirable to encourage the use of leaves in relation to the bark of roots or stems.

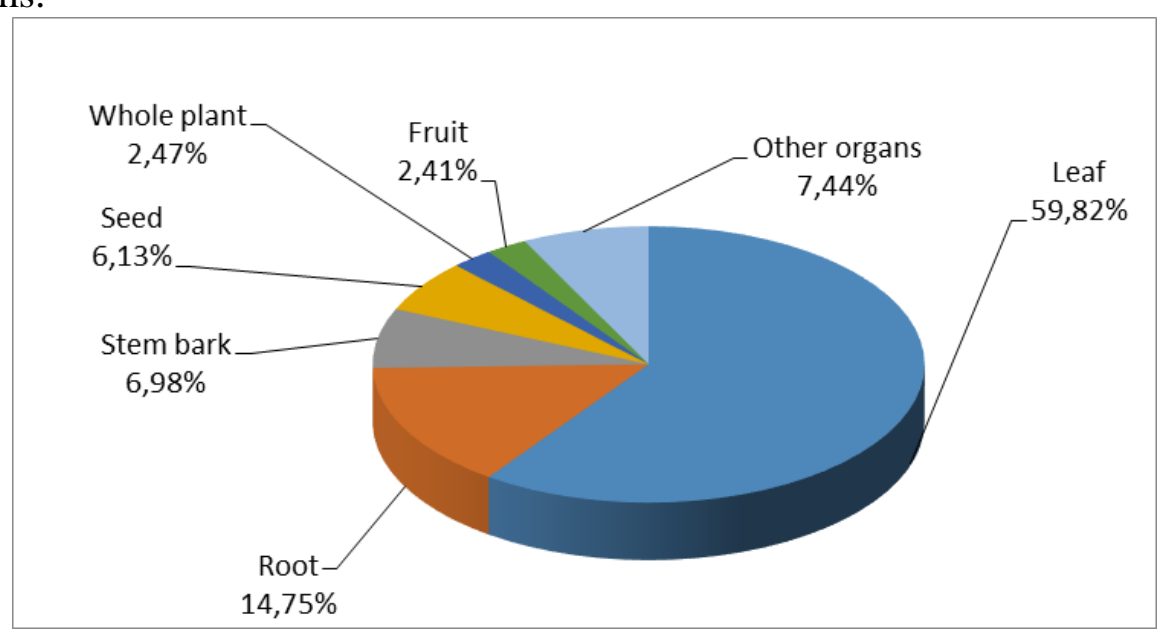

Figure 5: Plant organs used

\subsubsection{Mode of preparation of recipes}

In this study, the proportions of different methods of preparing plants are listed in Table 3. Among all the methods of preparation listed with 
Kimvula's traditional therapists, decoction and pounding are the most common. They collect respectively 2326 citations and 2292 citations, or 42.19 and $41.57 \%$. The other modes of preparation are slightly cited as indicated in Table 1.

The results of this study are consistent with those obtained by Musuyu (2006), Ataholo (1988), Lassa (2012) in DR Congo; Bitsindou (1996) in Congo-Brazzaville in Kindamba, Dibong et al. (2011) in the markets of Douala in Cameoun; Benlamdini et al. (2014) in Morocco, in the Eastern High Atlas (Haute Moulouya) and Koffi et al. (2009) in Côte d'Ivoire in the Krobou country. However, they differ from those obtained by Ilumbe (2006); Mabika (1983); Wome (1985); Magilu (2007) in DR Congo; Fézan et al. (2008) in Côte d'Ivoire, Bitsindou (1996) in Congo-Brazzaville in the Odzala National Park; Dibong et al. (2011) in Cameroon in the Douala markets; Oumar et al. (2014) in Senegal to Khossanto and Souad et al. (2010) in Morocco in the city of Kenitra. For these authors, maceration is the most used mode in the preparation of recipes. Whereas for Kawukpa and Angoyo (1994) among the Batiabetuwa of Mbiye Island in Kisangani (DRC), it is rather the infusion and the drying which are most appreciated in the preparation of the recipes.

Table 1: Mode of preparation of recipes

(Number of cit: number of citation and \%: percentage)

\begin{tabular}{lcc}
\hline Mode of preparation & Number of cit & $\mathbf{\%}$ \\
\hline Burn & 90 & 1,63 \\
Heat up & 86 & 1,56 \\
Cooking & 12 & 0,22 \\
Decoction & $\mathbf{2 3 2 6}$ & $\mathbf{4 2 , 1 9}$ \\
Oven drying & 1 & 0,02 \\
Shead condition drying & 2 & 0,04 \\
Solar drying & 1 & 0,02 \\
Crease & 152 & 2,76 \\
Rub & 144 & 2,61 \\
Scratch & 11 & 0,20 \\
Roast & 15 & 0,27 \\
Infusion & 1 & 0,02 \\
Pounding & $\mathbf{2 2 9 2}$ & $\mathbf{4 1 , 5 7}$ \\
Plant & 1 & 0,02 \\
Without preparation & 370 & 6,71 \\
Break up & 8 & 0,15 \\
Sap leaf & 1 & 0,02 \\
\hline General Total & $\mathbf{5 5 1 3}$ & $\mathbf{1 0 0 , 0 0}$ \\
\hline
\end{tabular}




\subsubsection{Administration Modes}

The different modes of administration are represented in figure 6 . The oral route is the most used mode of administration with 2511 of citations (45.55\%) followed by the anal route with 1217 of citations (22.08\%) and skin topical with 419 citations $(7.60 \%)$. The other routes of administration are poorly cited.

Similar results were also obtained in Bobangi (Ilumbe, 2006); in Kasaï-Occidental (Mabika, 1983); in the markets of the city of Kinshasa (Lassa, 2012); in the southwest of the Salonga National Park (Musuyu, 2006); among the Pende populations of the periphery of the INERA forest reserve of Kiyaka, (Magilu, 2007); in Cameroon in the Douala market (Dibong et al., 2011); Kindamba and Odzala National Park (Bitsindou, 1996); in Ivory Coast in the country Krobou, (Koffi, 2009). While in Kisangani, Wome (1985) noted the importance of the rectal route as a whole. Kawukpa and Angoyo (1994) among the Batiabetuwa of Mbiye Island in Kisangani, Lubini (1990) among the Yansi of between Kwilu-Kamastha and Magilu (2006) in Kisangani and Gungu also noted the predominance of the anal route during their investigations. According to Mato (2005) on the outskirts of the southwestern part of Salonga National Park, local application and the oral route are the most common directions for use.

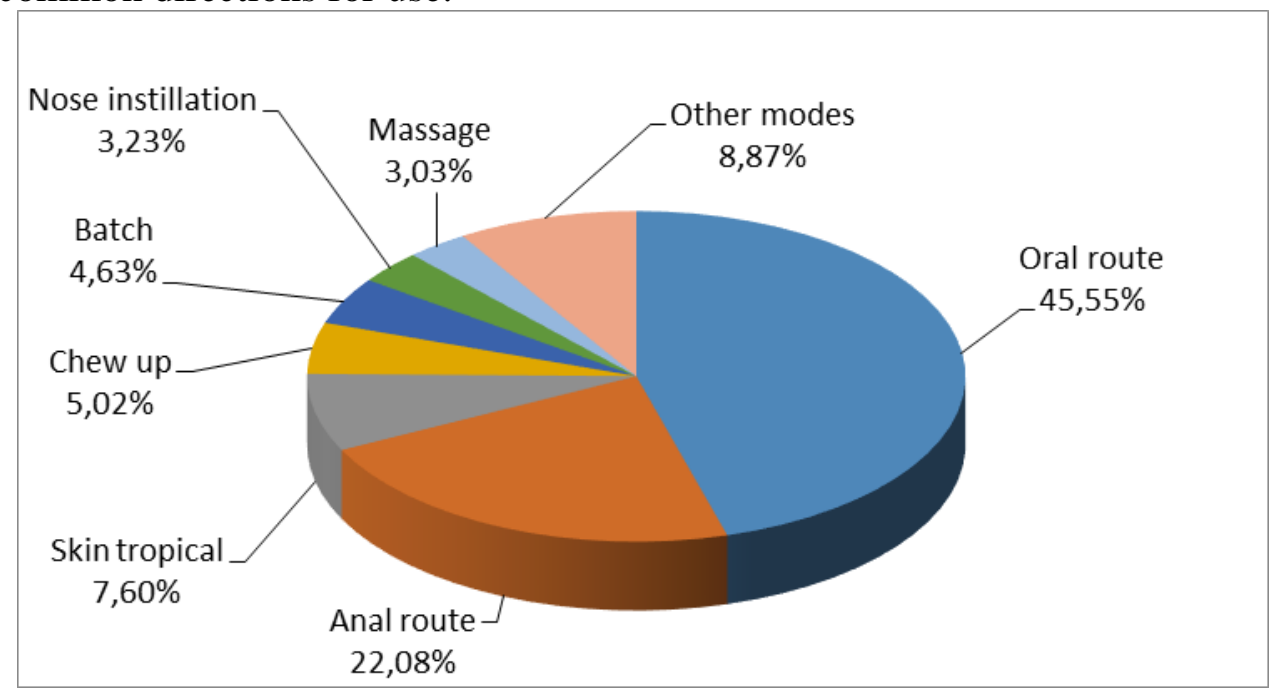

Figure 6: Mode of administration of drugs in Kimvula city

\subsection{Cultural Importance of Local Plants}

The medicinal plants used in the city of Kimvula with their values of the VUs, ICs and VAUs indices are presented in table 3 in the appendix.

The value-based cash arrangement (VUs) gives different results compared to the informant consensus value-based arrangement (ICs). If the classification based on VUs favors plants used for several uses, that based on 
the values of the index of consensus of informants favors plants used or known in several districts.

The classification made from the values of the index of the value of use of the species puts in first position the species Quassia africana (4.83), Canarium schweinfurthii (3.20), Moringa oleifera (2.50) with values greater than or equal to 2.50. By classifying the species according to the confirmation index (ICs), they are the species Ocimum gratissimum (0.78), Morinda morindoïdes (0.74), Disphania ambrosiö̈des (0.73), Senna occidentalis (0.72), Persea americana (0.61), Boerrhavia diffusa (0.60), Brillantaisia owariensis (0.60), Ocimum americanum (0.56), Securidaca longepedunculata (0.53) and Pentadiplandra brazzeana (0.50) values greater than or equal to 0.50 . By combining the values VUs and ICs into a use agreement value (VAUs), the plant species with a high use agreement value are Morinda morindoides (1.58), Ocimum gratissimum (1.23), Disphania ambrosiödes (1.20) and Moringa oleifera (1.13) with values greater than 1.10.

\subsection{Intra and Inter District Relations About Used of Medicinal Plants}

The lists of plants cited during the various interviews across the six districts were subjected to ascending hierarchical classifications. This in order to seek links between the different people interviewed across the different districts on the medicinal plants used in traditional medicine in the city of Kimvula.

\subsubsection{Classification based on criteria « used species in traditional medicine »}

This classification on the basis of the methods Nearest Neighbour of 6 districts and 188 plant species it possible to observe, 2 groups formed for the use of medicinal plants (figure 7). The first group (G1) is composed of the district inhabitant Mvula nlondi and the second group (G2) is composed of the districts inhabitant Kinata, Lona, Pado, Révolution and Winda. Analysis of the figure below shows that there is not a link concerning the use of plants between the inhabitant of group 1 and the inhabitant of group 2. By the wah, that there is a link concerning the use of plants between the Lona, Winda, Pado, Revolution and Kinata neighborhoods (Group 2). Three espcies characterized the group 1 like: Clematis hirsuta, Saccharum officinarum and Voacanga africana, and four especies Ceiba pentandra, Indigofera paracapitata, Maprounea africana and Ochna afzelii characterized the group 2. 


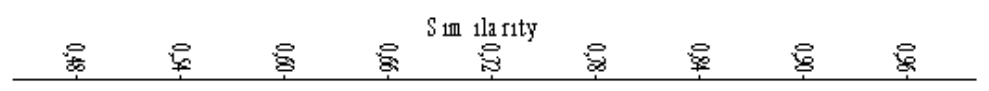

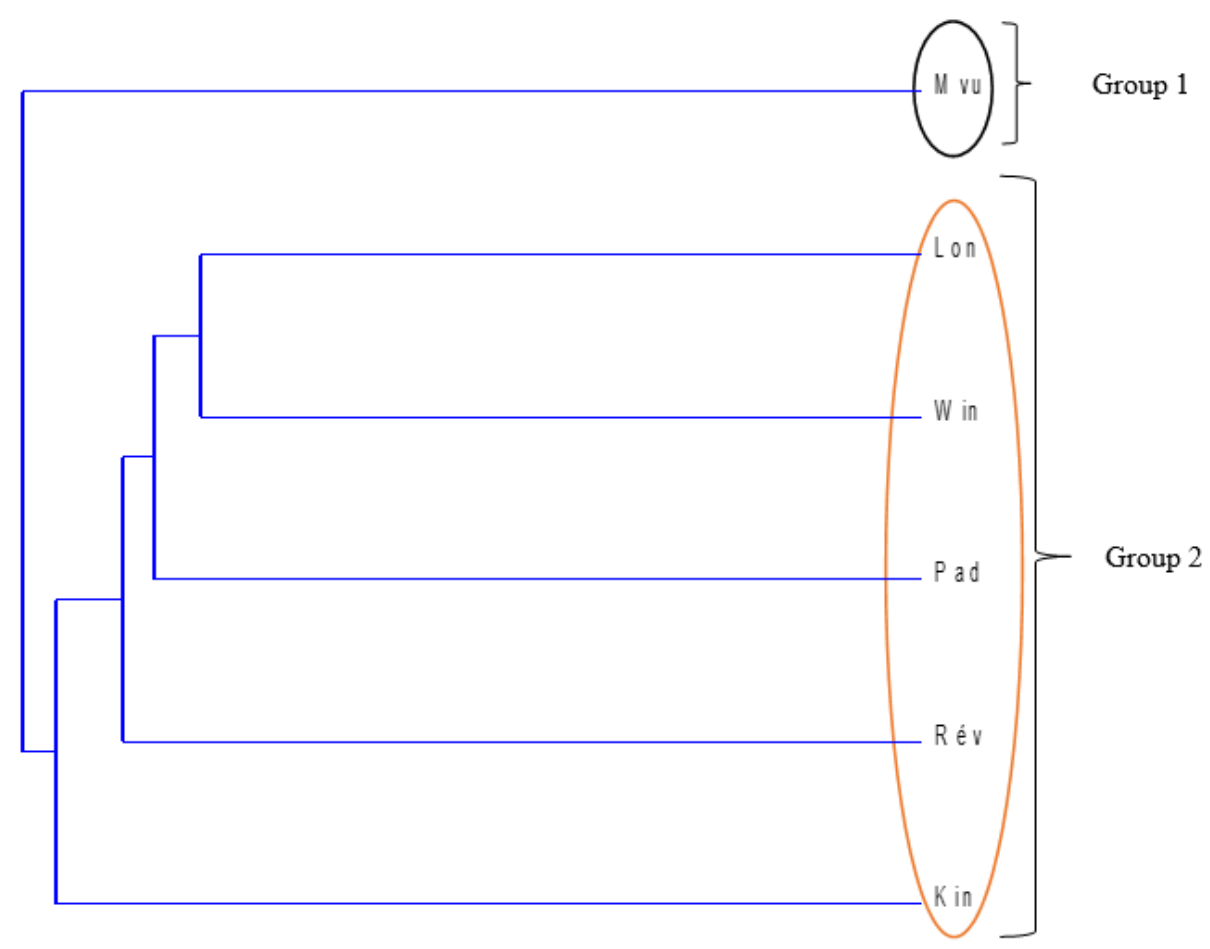

Figure 7: Dendrogram showing the different groups formed by the populations of different districts in the use of plants in traditional medicine according to the nearest neighbor method and Jaccard coefficient (Kin: Kinata, Lon: Lona, Mvu: Mvula nlondi, Pad: Pado, Rev:

Revolution and Win: Winda

\section{Conclusion}

This study has revealed the relative importance of traditional medicine in the primary health system in the city of Kimvula and at the same time confirms that the use of medicinal plants in the therapeutic field still persists despite the popularity of medicine modern. The ethnobotanical study of medicinal plants showed the presence of 188 medicinal species divided into 158 genera and 69 families. The most represented families are Fabaceae (22 species), Rubiaceae (11 species), Malvaceae (9 species) and Asteraceae (8 species). The leaf (59.82\%) is the most cited part and in the majority of cases, the plant parts are used fresh in the preparation of medicinal recipes; these are more usually made by decoction (42.19\%). As for the method of administration, the oral route is the most cited $(45.55 \%)$. The species with a high use agreement value are Morinda morindoïdes (1.58), Occimum gratissimum (1.23), Disphania ambrosioides (1.20) and Moringa oleifera 
(1.13). The medicinal species are used especially against diseases which constitute a real health problem such as anemia, cough, fever, stomach aches, spleen disorders, general pain, back pain, malaria, hemorrhoids, headache and diarrhea. However, despite their effectiveness, these therapeutic products have not been scientifically validated and the problems still lie in unwanted side effects, chronic toxicity and contraindications. These species deserve sustainable management because they are the most widely used and treat several indications or diseases. They can be integrated into sustainable management so that its plant resources exist for future generations. It would be desirable that sustainable management measures be taken to conserve these species.

Well will offer some of them to pharmacists and chemists for the control of therapeutic or toxic effects in order to select the truly effective plants. Mainly plants and popular recipes; it will be necessary to determine the indications and the dosage for each of them, this can be done through pharmacological monitoring of patients where the healer and the health worker or doctor work together; and to create gardens of medicinal plants to cultivate interesting species, and also to consider chemical and phytochemical studies with a view to determining the properties of these plants for their better use or the substitution of plant organs which regenerate with difficulty.

\section{References:}

1. Adjanohoun E. (1993). Tropical Forest and africaine pharmacopoeia. In Kabala, M.D., Maldaghe \& Mankoto ma Mbaelele. IZCNUNESCO-ACCT, 331-342.

2. Alexiades M.N. (1996). Selected guidelines for ethnobotanical research: A field manual. New York Botanical Garden.

3. Alexiades M.N. (1999). Ethnobotany of the Ese Eja: Plants, health, and change in an Amazonian society. City University of New York, Ph.D. Dissertation.

4. APG III, 2009. Angiosperm Phylogeny Group. Botanical Journal of the Linnean Society, 141:399-436.

5. Ataholo M. (1988) Plantes médicinales de Buta. Mémoire Inédit, Faculté des Sciences, Université de Kisangani, 84 p.

6. Augereau J.M. (2008). The médicinales plants. In Hallé F. \& Lieutaghi P. (eds). Aux origines des plantes. Paris: Fayard, 170-201 p.

7. Balée W. (1994). Análise preliminar de inventario florestal e a etnobotânica Ka'apor. Boletim do Museu Paráense. Emílio Goeldi, Ser. Bot., 2: 141-167.

8. Bastien J.W. (1987). Healers of the Andes. Kallawaya Herbalists and their Medicinal Plants. University of Utah Press, Salt Lake City, US. 
9. Benlamdini N., Mohamed E., Atmane R. et Lahien Z. (2014). Etude floristique et ethnobotanique de la flore médicinale du Haut Atlas Oriental (Haute Moulouya). J. Appl. Biosc. 78:6771 - 6787.

10. Bennett B. \& Prance G. T. (2000). Introduced plants in the indigenous pharmacopoeia of Northern South America. Economic Botany, 54: 90102.

11. Betti J.L (2001). Vulnérabilité des plantes utilisées comme antipaludiques dans l'arrondissement de Minton au sud de la Réserve de Biosphère du Dja (Cameroun). Syst. Geogr. 678p.

12. Byg A. et Balslev H. (2001) Diversity and use of palms in Zahamena, eastern Madagascar. Biodiversity and Conservation, 10: 951-970.

13. Bikandu K., Fruth B. et Lukoki L. (2018). Inventaire préliminaire des plantes médicinales vendues dans quelques marches de la partie Ouest de la ville de Kinshasa dans les différents marchés en RDCongo. EUE. $156 \mathrm{p}$.

14. Bikandu K.B (2012). Etude de quelques espèces médicinales cibles vendues dans les marchés de Kinshasa et leur disponibilité sur les formations végétales : "Cas de l'axe Kinshasa-Matadi et KinshasaKikwit ». Mémoire de DEA en Biologie, Fac. Sciences. Université de Kinshasa.

15. Bitsindou M. (1996). Enquêtes sur la phytothérapie traditionnelle à Kindamba et Odzala. Thése Doc., Univ. Libre de Bruxelles. pp. 186265

16. Bontemps (1993). Encyclopédie de santé familiale. Plantes remèdes naturels. Ed. GODEFROY, La Ferrière sur-Risle, 604p.

17. Caroline G., 2013. Guide de poche de phytothérapie. Quotidien Malin, ISBN : 978-2-84899-647-9, $32 \mathrm{p}$.

18. Casagrande D. G. (2002). Ecology, cognition, and cultural transmission of Tzeltal Maya medicinal plant knowledge. $\mathrm{PhD}$ dissertation. University of Georgia, Athens, Georgia, US.

19. Diafouka A. (1997). Analyse des usages des plantes médicinales dans quatre régions du Congo - Brazzaville. Thèse Doc., Université Libre de Bruxelles, $434 \mathrm{p}$.

20. Dibong S.D., Mpondo M.E., Ngoye A., Kwin M. et Betti J.L,. 2011. Ethnobotanique et phytomédecine des plantes médicinales de Douala, Cameroun. J. Appl. Biosc. 37 :2496 - 2507.

21. Fézan H.T., Guy M., Kohué C.C. et Clejesson H.B., 2008. Etudes de quelques plantes thérapeutiques utilisées dans le traitement de l'hypertension artérielle et du diabète : deux maladies émergentes en Côte d'Ivoire. Sciences \& Nature Vol. $5 \mathrm{~N}^{\circ} 1: 39-48$.

22. Jiofack T., Ayissi I., Fokunang C., Guedje N. et Kemeuze V., 2009. Ethnobotany and phytomedecine of the upper Nyong Valley forest in 
Cameroon. African Journal of Pharmacy and pharmacology 3(4):144 -150 .

23. Jiofack T., Fokunang C., Guedje N. et Kemeuze V., Fongnzossie E., Nkongmeneck B.A., Mapongmetsen P.M. et Tsabang N. (2010). Ethnobotanical regions of Cameroon. International Journal of Medecine and Medical Sciences 2(3):60 - 67.

24. Gafuene N. (2009). Contribution à l'inventaire des plantes médicinales utilisées au plateau de Bateke. Mémoire, Unikin, Fac. Sc. Dépt. Biol.

25. Geissler P. W., Harris S. A., Prince R. J., Olsen A., Achieng' Odhiambo R., Oketch-Rabah H., Madiega P. A., Andersen A. \& Mølgaard P., 2002. Medicinal plants used by Luo mothers and children in Bondo district, Kenya. Journal of Ethnopharmacology, 83: 39-54.

26. Heinrich M., Ankli A., Frei B., Weimann C. \& Sticher, O., 1998 b. Medicinal plants in Mexico: Healers' consensus and cultural importance. Social Science and Medicine, 47: 1859-1871.

27. Ilumbe G., 2006. Usage des plantes chez les peuples de Bobangi. Mémoire de DEA, U.L.B, 72 p.

28. Ilumbe G., 2010. Utilisation des plantes en médecine traditionnelle par les Pygmées (Ba-Twa) et les Bantous (Ba-Oto) du territoire de Bikoro, Province de l'Equateur en R.D.C. Thèse de doctorat, U.L.B, 251 p.

29. Ilumbe G.B., Van Damme P., Lukoki L.F., Joiris V., Visser M. et Lejoly J., 2014. Contribution à l'étude des plantes médicinales dans le traitement des hémorroïdes par les pygmées Twa et leur voisin Oto de Bikoro, en RDC. Journal en ligne de l'ACASTI et du CEDESURK. Vol. 2. $\mathrm{N}^{\circ} 1$ p. 9.

30. Intissar A.O., 2016. Enquête ethnobotanique à propos des plantes médicinales utilisées dans le traitement traditionnel du diabète de type II à Marrakech Thèse de doctorat, Université Cadi Ayyad, 123 p.

31. Kalanda K., Ataholo M. \& Ilumbe B. (1995). Contribution à la connaissance des plantes médicinales du Haut-Zaïre: Plantes antihémorroïdaires de Kisangani. Rev. Méd. Pharm. Afr. 9 (1): 51-58.

32. Kawukpa et Angoyo (1994). Plantes utiles chez les Batiabetuwa de l'Ile Mbiye, Kisangani, Zaïre. African Study Monograph, 15 (2) : pp. 49-68.

33. Kent M. \& Coker P. (1996). Vegetation description and analysis. A practical approach. Chichester: Wiley.

34. Kerharo J. \& Adam J.G. (1974). Pharmacopée sénégalaise traditionnelle. Plantes médicinales et toxiques. Vigot Frères. Paris, $1011 \mathrm{p}$.

35. Kimbungu K., 2003. Quelques plantes médicinales du Bas-Congo et leurs usages. Publication du Jardin Botanique de Kisantu, 189 p. 
36. Kimmer 2002. Weaving traditional ecological knowledge into biological education: a call to action. BioScience, 52: 432-438.

37. Kanyinda B. (1983). Formulaire thérapeutique Traditionnelle Zaïrois, vol. I, Institut de Recherche en Sciences de la Santé Presse ; Kinshasa.

38. Koffi N., Bengré K., Guédé N., Dossahoua T. et Laurent A. (2009). Screening phytochimique de quelques plantes médicinales ivoiriennes utilisées en pays Krobou (Agboville, Côte d'Ivoire). Sciences \& Nature Vol. $6 \mathrm{~N}^{\circ} 1: 1-15$.

39. K.N. Ngbolua, C.L. Inkoto, N.L. Mongo, C.M. Ashande, Y.B. Masens, P.T. Mpiana, 2019. Étude ethnobotanique et floristique de quelques plantes médicinales commercialisées à Kinshasa, République Démocratique du Congo. Rev. Mar. Sci. Agron. Vét. (2019) 7 (1): 118128

40. Lassa K., 2007. Inventaire préliminaire des plantes médicinales vendues dans quelques marchés de la partie Est de la ville de Kinshasa «Cas de districts de Mont-Amba et Tshangu ». Mémoire, Unikin, Fac. Sc. Dépt. Biol. 156 p + annexes.

41. Lassa K., 2012. Valorisation des produits forestiers non ligneux (PFNL) d'origine végétale vendus dans les marchés et leur disponibilité dans les environs de la ville de Kinshasa: "Cas de CADIM ». Mémoire de DEA en Biologie, Fac. Sciences. Université de Kinshasa. 353 p.

42. Lathan et al., 2007. Plantes utiles du Bas-Congo, R.D.C. $2^{\text {ème }}$ éd. Paul Lathan, $343 \mathrm{p}$.

43. Lebrun J., 1947. La végétation de la plaine alluviale au Sud du lac Edouard. Exploration du Nat. Albert : mission J. Lebrun (1937-1938), fasc. $1: 471-800$.

44. Legendre P. et Legendre L. (1998) Numerical Ecology. Developments in Environnemental Modelling, 20, Elsevier Sciences B.V., Amsterdam, $853 \mathrm{p}$.

45. Liengola I. (2001) Contribution à l'étude des plantes alimentaires spontanées chez les Turumbu et Lokele du District de la Tshopo, Province Orientale, R.D. Congo. Systematics and Geography of Plants, 71 (2) : 687-698.

46. Leonti M., Sticher O., and Heinrich, M. (2002). Medicinal plants of the Popoluca, México:

47. Lubini A., 1990. Les plantes utilisées en médecine traditionnelle par les Yansi de l'entre Kwilu-Kamtsha (Zaïre) Mitt. Inst. Allg. Bot. Hamburg Band $23 \mathrm{~b}$, Comptes rendus de la XIIè Réunion plénière de L'Aetfat. Symposium VIII, 1007-1020. 
48. Lukoki L. F., 2011. Médecine traditionnelle Kongo. Nkisi mi Bakulu. Centre Information de la Faculté d'Economie et développement. Université Catholique du Congo. Kinshasa, 172 p.

49. Lumbu S., Kahumba B., Kahambwe T., Mbayo K., Kalonda M., Mwamba M., Penge O (2005). Contribution à l'étude de quelques plantes médicinales antidiarrhéiques en usages dans la ville de Lubumbashi et ses environs. Annales de Pharmacie, Vol 3, $\mathrm{N}^{\circ} 1$, pp. 75-86.

50. Mabika K. (1983). Plantes médicinales et médecine traditionnelle au Kasaï occidental. Thèse de doctorat, Université de Kisangani, 433 p.

51. Magilu M. (2006). Etude éthnobotanique et production fruitière de Treculia Africana Decne de la région de Kisangani (Province orientale) et de la région de Gungu (Province de Bandundu) / R.D.C. Mémoire Inédit, Fac. Sc., Unikis, 72 p.

52. Magilu M. (2007). Etude éthnobotanique chez les populations Pende de la périphérie de la réserve forestière de l'INERA de Kiyaka (Kikwit), pp. 45-87.

53. Magurran A.E. (2004). Measuring biological diversity. Blackwell, Malden, Mass.; Oxford.

54. MacRae H.M., McLeod R.S. (1995). Comparison of hemorrhoidal treatment modalities. A meta-analysis. International Journal of Colorectal Disease; 38:687-94

55. Makumbelo E., Lukoki L., J Paulus.J.s.j \& Luyindula N. (2008). Stratégie de valorisation des espèces ressources des produits non ligneux de la savane des environs de Kinshasa : II. Enquête ethnobotanique (aspects médicinaux). Tropicultura, 26 (3) : 129-134

56. Makumbelo E., Lukiki L. et Bikoko E. (2018). Pratique traditionnelle de gestion durable des espèces végétales utiles. Cas de la savane de Kinshasa. RDCongo. Journal en ligne de l'ACASTI et du CEDESURK. Vol. $6 \mathrm{~N}^{\circ} 2$ p. $108-114$.

57. Martin, G. J. (1995). Ethnobotany. A methods manual. Chapman and Hall, London, UK. ISBN 041248370X

58. Mato K.B., 2005. Savoir-faire local dans le périphérique de la partie Sud-Ouest du Parc National de la Salonga. Mémoire DEA en Biologie. Fac. Sciences, Université de Kinshasa. 91 p + annexes.

59. Milliken W. (1997a). Traditional anti-malarial medicine in Roraima, Brazil. Economic

60. Milliken W., Miller R. P., Pollard S. R. \& Wandelli E. V. (1992). Ethnobotany of Waimiri Atroari Indians of Brasil. Royal Botanic Gardens, Kew, London, UK, 146 pp. 
61. Musuyu D., 2006. Contribution à la revue des plantes médicinales des Nkundo au Sud-Ouest du Parc National de la Salonga. Mémoire DEA en Biologie, Fac. Sciences. Université de Kinshasa. 108 p + annexes.

62. Nzuki B.F., 2016. Recherches ethnobotaniques sur les plantes médicinales dans la région de Mbanza-Ngungu, RDC. Thèse de Doctorat $(\mathrm{PhD})$, Faculté des Sciences en Bio-Ingénierie, Université de Gand, Belgique, p. 349.

63. O.M.S. (1993). Classification statistique internationale des maladies et des problèmes de santé connexes. 10 ème révision, vol.1, OMS, Genève, $1335 \mathrm{p}$.

64. OMS (2002). Stratégies de l'OMS pour la médecine traditionnelle pour 2002-2005. Organisation mondiale de la santé, 7.

65. OMS. (2004). Atelier sur l'institutionnalisation de la Médecine Traditionnelle dans les systèmes de santé, Cotonou, Bénin, du 13 au 15 septembre 2004.

66. O.U.A. (1985). Pharmacopée africaine. Vol. 1. CSTR/OUA, Lagos, Nigeria, $274 \mathrm{p}$.

67. Ould Mohamed V.H. et Abdallahi (2009). Contribution à l'étude des plantes médicinales de Mauritanie. ANN. Univ. Lomé (Togo). S2RIE Sciences, Tome XVII :9 - 27.

68. Oumar N.G., Oumar S. et Leonard E. (2014). Richesse de la pharmacopée malinké: rôle médicinal de l'arbre a Khossanto: (Kédougou, Sénégal Oriental). J. Appl. Biosc. 74 :6043 - 6058.

69. Paulin O., Anne M.L., Joseph B. et Sita G. (2006). La flore médicinale de la forêt classée de Niangoloko (Burkinafaso). Etudes sur la flore et la végétation du Burkinafaso, Frankfurt 10, 5-16.

70. Phillips O.L., Gentry A.H., Reynel C., Wilkin P. \& Ga'lvez-Durand B.C. (1994). Quantitative ethnobotany and Amazonian conservation. Conservation Biology 8: 225-248.

71. Sofowora A. (1996). Plantes médicinales et médecine traditionnelle d'Afrique. Ed. Karthala, Paris, 375 p.

72. Spichiger R.E., Savolainen V., Figeat M. \& Jeanmonod D., 2004. Botanique systématique des plantes à fleurs: une approche phylogénétique nouvelle des Angiospermes des régions tempérées et tropicales. $3^{\text {ème }}$ ed. Revue et corrigée, Presses polytechniques et universaires romandes, Lausanne, $413 \mathrm{p}$.

73. Souâda H., Azzeddine K., Hafsa L. et Mohamed T. (2007). Analyses floristique et ethnobotanique des plantes vasculaires médicinales utilisées dans la région de Rabat (Maroc Occidental). Lazaroa 28 :93 -100 . 
74. Souad S., Mohamed F., Lahien Z. et Allal D. (2010). Etudes floristique et ethnobotanique des plantes médicinales de la ville de Kénitra (Maroc). Lazaroa $31: 133$ - 146.

75. Stokes M.E., Davis C.S. \& Koch G.G. (2000). Categorical data analysis using the SAS system. 2nd ed. NC, USA, SAS Institute Inc. 18.

76. Toirambe (2002). Valorisation des produits forestiers non ligneux dans la réserve de biosphère de Luki - Bas-Congo. ERAIFT. Université de Kinshasa, RDC. 161 p.

77. Trotter R.T. \& Logan M.H. (1986). Informant consensus: a newapproach for identifying potentially effective medicinal plants. In: Etkin, N.L. (Ed.), Plants in Indigenous Medicine and Diet. Redgrave Publishing Company, Bedford Hill, New York, pp. 91-112.Voeks R.A. (2004). Disturbance pharmacopoeias: medicine and myth from the humid tropics. Annals of the Association of American Geographers 94, 868-888

78. White F. (1983). The vegetation map of Africa. A descriptive memoir. UNESCO, Natural Ressources Research, 20 : 1-356.

79. Wome B. (1985). Recherches ethnopharmacognosiques sur les plantes médicinales utilisées en médecine traditionnelle à Kisangani (HautZaïre). Thèse Doct. Univ. Libre de Bruxelles, 561 p.

80. Youssouf Sylla, Dieudonné Kigbafori Silue, Kigninma Ouattara et Mamidou Witabouna Kone (2018). Etude ethnobotanique des plantes utilisées contre le paludisme par les tradithérapeutes et herboristes dans le district d'Abidjan (Côte d'Ivoire). Int. J. Biol. Chem. Sci. 12(3): 1380-1400, ISSN 1997-342X (Online), ISSN 1991-8631 (Print)

81. Zerbo P., Millogo-Rasodimby J., Nacoulma-Ouedraogo O. G. et Van Damme P. (2007). Contribution à la connaissance des plantes médicinales utilisées dans les soins infantiles en pays San, au Burkina Faso. Int. J. Biol. Chem. Sci. 1(3): 262-274 


\section{Appendix}

Table 2: Distribution of genera and species in botanical families

\begin{tabular}{|c|c|c|c|c|}
\hline Botanical Family & $\begin{array}{c}\text { Number } \\
\text { of } \\
\text { genera }\end{array}$ & $\%$ & $\begin{array}{c}\text { Number } \\
\text { of } \\
\text { species }\end{array}$ & $\%$ \\
\hline Acanthaceae & 2 & 1,27 & 2 & 1,06 \\
\hline Amaranthaceae & 2 & 1,27 & 2 & 1,06 \\
\hline Amaryllidaceae & 1 & 0,63 & 1 & 0,53 \\
\hline Anacardiaceae & 2 & 1,27 & 2 & 1,06 \\
\hline Anisophyllaceae & 1 & 0,63 & 1 & 0,53 \\
\hline Annonaceae & 2 & 1,27 & 3 & 1,60 \\
\hline Apocynaceae & 5 & 3,16 & 6 & 3,19 \\
\hline Araceae & 4 & 2,53 & 4 & 2,13 \\
\hline Arecaceae & 2 & 1,27 & 2 & 1,06 \\
\hline Asparagaceae & 2 & 1,27 & 2 & 1,06 \\
\hline Asteraceae & 8 & 5,06 & 8 & 4,26 \\
\hline Bignoniaceae & 1 & 0,63 & 1 & 0,53 \\
\hline Brassicaceae & 1 & 0,63 & 1 & 0,53 \\
\hline Burseraceae & 2 & 1,27 & 2 & 1,06 \\
\hline Caricaceae & 1 & 0,63 & 1 & 0,53 \\
\hline Cecropiaceae & 1 & 0,63 & 1 & 0,53 \\
\hline Celastraceae & 1 & 0,63 & 1 & 0,53 \\
\hline Chrysobalanaceae & 1 & 0,63 & 1 & 0,53 \\
\hline Clusiaceae & 1 & 0,63 & 2 & 1,06 \\
\hline Combretaceae & 1 & 0,63 & 2 & 1,06 \\
\hline Commelinaceae & 1 & 0,63 & 1 & 0,53 \\
\hline Connaraceae & 1 & 0,63 & 1 & 0,53 \\
\hline Convolvulaceae & 1 & 0,63 & 1 & 0,53 \\
\hline Costaceae & 1 & 0,63 & 2 & 1,06 \\
\hline Crassulaceae & 1 & 0,63 & 1 & 0,53 \\
\hline Cucurbitaceae & 5 & 3,16 & 5 & 2,66 \\
\hline Cyperaceae & 1 & 0,63 & 1 & 0,53 \\
\hline Dioscoreaceae & 1 & 0,63 & 3 & 1,60 \\
\hline Ebenaceae & 1 & 0,63 & 1 & 0,53 \\
\hline Euphorbiaceae & 10 & 6,33 & 10 & 5,32 \\
\hline Fabaceae & 17 & 10,76 & 22 & 11,70 \\
\hline Gisekiaceae & 1 & 0,63 & 1 & 0,53 \\
\hline Hypericaceae & 2 & 1,27 & 2 & 1,06 \\
\hline Hypolepidaceae & 1 & 0,63 & 1 & 0,53 \\
\hline Iridaceae & 1 & 0,63 & 1 & 0,53 \\
\hline Lamiaceae & 3 & 1,90 & 5 & 2,66 \\
\hline Lauraceae & 1 & 0,63 & 1 & 0,53 \\
\hline Loganiaceae & 1 & 0,63 & 4 & 2,13 \\
\hline Malvaceae & 9 & 5,70 & 9 & 4,79 \\
\hline Marantaceae & 1 & 0,63 & 1 & 0,53 \\
\hline Menispermaceae & 1 & 0,63 & 1 & 0,53 \\
\hline Moraceae & 3 & 1,90 & 4 & 2,13 \\
\hline Moringaceae & 1 & 0,63 & 1 & 0,53 \\
\hline Musaceae & 1 & 0,63 & 2 & 1,06 \\
\hline Myrtaceae & 3 & 1,90 & 4 & 2,13 \\
\hline
\end{tabular}




\begin{tabular}{lcccc} 
Nyctaginaceae & 1 & 0,63 & 1 & 0,53 \\
Nymphaeaceae & 1 & 0,63 & 1 & 0,53 \\
Ochnaceae & 2 & 1,27 & 2 & 1,06 \\
Olacaceae & 1 & 0,63 & 1 & 0,53 \\
Passifloraceae & 2 & 1,27 & 2 & 1,06 \\
Pedaliaceae & 1 & 0,63 & 2 & 1,06 \\
Pentadiplandraceae & 1 & 0,63 & 1 & 0,53 \\
Phyllanthaceae & 2 & 1,27 & 3 & 1,60 \\
Piperaceae & 1 & 0,63 & 1 & 0,53 \\
Poaceae & 5 & 3,16 & 6 & 3,19 \\
Polygalaceae & 1 & 0,63 & 1 & 0,53 \\
Ranunculaceae & 1 & 0,63 & 1 & 0,53 \\
Rubiaceae & $\mathbf{1 0}$ & $\mathbf{6 , 3 3}$ & $\mathbf{1 1}$ & $\mathbf{5 , 8 5}$ \\
Rutaceae & 1 & 0,63 & 3 & 1,60 \\
Salicaceae & 1 & 0,63 & 1 & 0,53 \\
Scrophulariaceae & 2 & 1,27 & 2 & 1,06 \\
Simaroubaceae & 1 & 0,63 & 1 & 0,53 \\
Solanaceae & 5 & 3,16 & 8 & 4,26 \\
Talinaceae & 1 & 0,63 & 1 & 0,53 \\
Theaceae & 1 & 0,63 & 1 & 0,53 \\
Verbenaceae & 3 & 1,90 & 3 & 1,60 \\
Vitaceae & 1 & 0,63 & 1 & 0,53 \\
Xantorrhoeaceae & 1 & 0,63 & 1 & 0,53 \\
Zingiberaceae & 2 & 1,27 & 3 & 1,60 \\
\hline Total & $\mathbf{1 5 8}$ & $\mathbf{1 0 0}$ & $\mathbf{1 8 8}$ & $\mathbf{1 0 0}$ \\
\hline
\end{tabular}

Table 3: List of species used in the city of Kimvula with their use agreement values. NI: number of informants, NQ: number of neighborhoods, NM: number of diseases, NR: number of recipes, NC: number of citations, VUs: use value of the species, CIs: confirmation index and VAUs: use agreement value.

\begin{tabular}{|c|c|c|c|c|c|c|c|c|}
\hline Species & N.I & N.Q & N.M & N.R & N.C & VUs & ICs & VAUs \\
\hline Abelmoschus esculentus (L.) & & & & & & & & \\
\hline Moench (Malvaceae) & 4 & 2 & 2 & 2 & 4 & 1,00 & 0,02 & 0,02 \\
\hline Abrus precatorius L. (Fabaceae) & 6 & 3 & 1 & 5 & 6 & 1,00 & 0,03 & 0,03 \\
\hline $\begin{array}{l}\text { Acanthospermum hispidum DC. } \\
\text { (Asteraceae) }\end{array}$ & 39 & 5 & 8 & 22 & 59 & 1,51 & 0,21 & 0,32 \\
\hline $\begin{array}{l}\text { Aframomum alboviolaceum } \\
\text { (Ridl.) K. Schum. (Zingiberaceae) } \\
\text { Aframomum melegueta K. }\end{array}$ & 70 & 6 & 12 & 34 & 100 & 1,43 & 0,38 & 0,54 \\
\hline $\begin{array}{l}\text { Schum.(Zingiberaceae) } \\
\text { Albizzia adianthifolia (Schum.) }\end{array}$ & 1 & 1 & 1 & 1 & 1 & 1,00 & 0,01 & 0,01 \\
\hline W. Wight (Fabaceae) & 7 & 3 & 6 & 6 & 9 & 1,29 & 0,04 & 0,05 \\
\hline $\begin{array}{l}\text { Alchornea cordifolia (Schum \& } \\
\text { Thonn.) Müll. Arg. }\end{array}$ & & & & & & & & \\
\hline $\begin{array}{l}\text { (Euphorbiaceae) } \\
\text { Allium sativum }\end{array}$ & 54 & 6 & 7 & 21 & 62 & 1,15 & 0,29 & 0,33 \\
\hline $\begin{array}{l}\text { L. (Amaryllidaceae) } \\
\text { Aloe congolensis De Wild \& T. }\end{array}$ & 5 & 2 & 4 & 4 & 9 & 1,80 & 0,03 & 0,05 \\
\hline Durand. (Xantorrhoeaceae) & 83 & 6 & 6 & 20 & 94 & 1,13 & 0,45 & 0,51 \\
\hline
\end{tabular}


Anchomanes difformis (Blume)

Engl. (Araliaceae)

Anisophyllea quangensis Engl. ex

Henriques (Anisophyllacee)

Annona senegalensis Pers

(Annonaceae)

Arachis hypogaea L. (Fabaceae)

Argocoferosus capensis L.

(Rubiaceae)

Barteria fustilosa (Mast.)

Sleumer (Passifloraceae)

Bidens pilosa L. (Asteraceae)

Boerrhavia diffusa $\mathrm{L}$.

(Nyctaginaceae)

Brassica oleracea L.

(Brassicaceae)

Bridelia ferruginea Benth.

(Phyllanthaceae)

Brillantaisia owariensis P. Beauv.

(Acanthaceae)

Bryophyllum pinnatum (Lam.)

Oken (Crassulaceae)

Cajanus cajan (L.) Millsp.

(Fabaceae)

Camelia sinensis L. (Theaceae)

Canarium schweinfurthii Engl.

(Burseraceae)

Capsicum frutescens $\mathrm{L}$.

(Solanaceae)

Capsicum velutinum $\mathrm{L}$.

(Solanaceae)

Carica papaya L. (Caricaceae)

Catharanthus roseus (L.) G. Don

(Apocynaceae)

Ceiba pentandra (L.) Gaertn

(Malvaceae)

\begin{tabular}{|c|c|c|c|c|c|c|c|}
\hline 4 & 1 & 1 & 1 & 4 & 1,00 & 0,02 & 0,02 \\
\hline 4 & 2 & 1 & 1 & 4 & 1,00 & 0,02 & 0,02 \\
\hline 71 & 5 & 10 & 28 & 82 & 1,15 & 0,38 & 0,44 \\
\hline 38 & 6 & 13 & 26 & 44 & 1,16 & 0,20 & 0,24 \\
\hline 1 & 1 & 2 & 2 & 2 & 2,00 & 0,01 & 0,01 \\
\hline 4 & 2 & 4 & 4 & 5 & 1,25 & 0,02 & 0,03 \\
\hline 56 & 6 & 11 & 26 & 92 & 1,64 & 0,30 & 0,49 \\
\hline 111 & 6 & 10 & 23 & 178 & 1,60 & 0,60 & 0,96 \\
\hline 2 & 1 & 1 & 1 & 2 & 1,00 & 0,01 & 0,01 \\
\hline 31 & 5 & 8 & 16 & 37 & 1,19 & 0,17 & 0,20 \\
\hline 111 & 6 & 22 & 58 & 159 & 1,43 & 0,60 & 0,85 \\
\hline 16 & 3 & 5 & 8 & 18 & 1,13 & 0,09 & 0,10 \\
\hline 1 & 1 & 1 & 1 & 1 & 1,00 & 0,01 & 0,01 \\
\hline 3 & 1 & 1 & 1 & 3 & 1,00 & 0,02 & 0,02 \\
\hline 5 & 3 & 7 & 9 & 16 & 3,20 & 0,03 & 0,09 \\
\hline 42 & 5 & 14 & 29 & 56 & 1,33 & 0,23 & 0,30 \\
\hline 3 & 2 & 3 & 1 & 2 & 0,67 & 0,02 & 0,01 \\
\hline 28 & 4 & 11 & 17 & 40 & 1,43 & 0,15 & 0,22 \\
\hline 9 & 1 & 8 & 13 & 21 & 2,33 & 0,05 & 0,11 \\
\hline 31 & 5 & 2 & 11 & 31 & 1,00 & 0,17 & 0,17 \\
\hline 1 & 1 & 1 & 1 & 1 & 1,00 & 0,01 & 0,01 \\
\hline 44 & 6 & 18 & 35 & 73 & 1,66 & 0,24 & 0,39 \\
\hline 10 & 4 & 6 & 9 & 12 & 1,20 & 0,05 & 0,06 \\
\hline 13 & 4 & 4 & 7 & 14 & 1,08 & 0,07 & 0,08 \\
\hline 1 & 1 & 1 & 1 & 1 & 1,00 & 0,01 & 0,01 \\
\hline 7 & 2 & 3 & 6 & 7 & 1,00 & 0,04 & 0,04 \\
\hline
\end{tabular}

Celosia trigyna (L.) R. King \& H.

(Amaranthaceae)

Chromolaena odorata $\mathrm{L}$.

(Asteraceae)

Cissus aralioides (Welw \&

Baker) Planch (Vitaceae)

Citrus limon (L.) Burn.F.

(Rutaceae)

Citrus reticulata Blanco

(Rutaceae)

Citrus sinensis (L.) Burn.F.

(Rutaceae) 
Clematis hirsuta Guill \& Perr

(Ranunculaceae)

Clerodendrum uncinatum Schinz

(Verbenaceae)

Cnestis ferruginea DC.

(Connaraceae)

Coffea canephora Pierre \&

Fröhner (Rubiaceae)

Cogniauxia podoleana Baill.

(Cucurbitaceae)

Cola acuminata (P. Beauv.)

Schott et Endl. (Malvaceae)

Colocasia esculenta (L.) Schott

(Araceae)

Combretum psidioides Welw.

(Combretaceae)

Combretum racemosum P. Beauv.

(Combretaceae)

Costus afer Ker-Gawel

(Costaceae)

Costus lucanusianus J. Braun \&

K. Schum. (Costaceae)

Cratespermum laurinum (Poir.)

Benth (Rubiaceae)

Crossopteryx febrifuga (Afzel.)

Benth (Rubiaceae)

Croton angolensis Müll.Arg.

(Euphorbiaceae)

Cryptolepis angolensis Welw. ex

Hiern (Apocynaceae)

Cucumeropsis mannii Naud.

(Cucurbitaceae)

Cycnium camporum Engl.

(Scrophulariaceae)

Cymbopogon citratus (DC.) Stapf.

(Poaceae)

Cymbopogon densiflorus (Steud.)

Stapf. (Poaceae)

Cyperus articulatus L.

(Cyperaceae)

Dacryodes edulis (G. Don) H.J.

Lam. (Burseraceae)

Dalbergia rufa G. Don (Fabaceae)

Dalechampia scandens L.

(Euphorbiaceae)

Datura stramonium L.

(Solanaceae)

Dialium pachyphyllum Harms

(Fabaceae)

\begin{tabular}{|c|c|c|c|c|c|c|c|}
\hline 1 & 1 & 1 & 1 & 1 & 1,00 & 0,01 & 0,01 \\
\hline 2 & 1 & 1 & 1 & 2 & 1,00 & 0,01 & 0,01 \\
\hline 5 & 2 & 2 & 2 & 5 & 1,00 & 0,03 & 0,03 \\
\hline 22 & 5 & 7 & 14 & 27 & 1,23 & 0,12 & 0,15 \\
\hline 6 & 2 & 5 & 5 & 10 & 1,67 & 0,03 & 0,05 \\
\hline 24 & 6 & 12 & 15 & 40 & 1,67 & 0,13 & 0,22 \\
\hline 3 & 2 & 2 & 2 & 3 & 1,00 & 0,02 & 0,02 \\
\hline 4 & 3 & 5 & 5 & 5 & 1,25 & 0,02 & 0,03 \\
\hline 3 & 1 & 1 & 1 & 3 & 1,00 & 0,02 & 0,02 \\
\hline 35 & 6 & 17 & 31 & 66 & 1,89 & 0,19 & 0,35 \\
\hline 21 & 5 & 11 & 15 & 29 & 1,38 & 0,11 & 0,16 \\
\hline 1 & 1 & 1 & 1 & 1 & 1,00 & 0,01 & 0,01 \\
\hline 11 & 4 & 7 & 8 & 17 & 1,55 & 0,06 & 0,09 \\
\hline 12 & 4 & 6 & 6 & 15 & 1,25 & 0,06 & 0,08 \\
\hline 1 & 1 & 1 & 1 & 1 & 1,00 & 0,01 & 0,01 \\
\hline 1 & 1 & 1 & 1 & 1 & 1,00 & 0,01 & 0,01 \\
\hline 3 & 2 & 2 & 2 & 3 & 1,00 & 0,02 & 0,02 \\
\hline 34 & 6 & 10 & 14 & 76 & 2,24 & 0,18 & 0,41 \\
\hline 27 & 5 & 7 & 11 & 32 & 1,19 & 0,15 & 0,17 \\
\hline 6 & 3 & 3 & 3 & 6 & 1,00 & 0,03 & 0,03 \\
\hline 28 & 5 & 4 & 9 & 31 & 1,11 & 0,15 & 0,17 \\
\hline 4 & 2 & 3 & 2 & 4 & 1,00 & 0,02 & 0,02 \\
\hline 7 & 2 & 5 & 5 & 8 & 1,14 & 0,04 & 0,04 \\
\hline 10 & 2 & 7 & 10 & 16 & 1,60 & 0,05 & 0,09 \\
\hline 13 & 2 & 8 & 9 & 16 & 1,23 & 0,07 & 0,09 \\
\hline
\end{tabular}


Dichrostachys cinerea (L.) Wight \& Arn. (Fabaceae)

Dioscorea bulbifera L.

(Dioscoreaceae)

Dioscorea dumetorum (Kunth)

Pax. (Dioscoreaceae)

Dioscorea praehensilis Benth.

(Dioscoreaceae)

Diospyros heterotricha (B.L.

Burtt) F. (Ebenaceae)

Dysphania ambrosioides (L.)

Mosiyikin \& Clements

(Amaranthaceae)

Dracaena acutissima Hua

(Asparagaceae)

Elaeis guinneensis L. (Arecaceae)

Eleusine indica (L.) Gaertn

(Poaceae)

Emilia coccinea (Sims) G. Don

(Asteraceae)

Erythrophloeum africanum

(Welw.) Harms (Fabaceae)

Erythrophloeum suaveolens

(Guill. Et Perr.) Brenan

(Fabaceae)

Eucalyptus globulus Labil.

(Melastomataceae)

Euphorbia trigona Haw.

(Euphorbiaceae)

Ficus exasperata Vahl.

(Moraceae)

Ficus thonningii Blume

(Moraceae)

Garcinia huillensis Welw. ex

Oliv. (Clusiaceae)

Garcinia kola Heckel

(Clusiaceae)

Gardenia ternifolia Schumach \&

\begin{tabular}{|c|c|c|c|c|c|c|c|}
\hline 2 & 2 & 4 & 4 & 4 & 2,00 & 0,01 & 0,02 \\
\hline 1 & 1 & 1 & 1 & 1 & 1,00 & 0,01 & 0,01 \\
\hline 2 & 1 & 1 & 1 & 2 & 1,00 & 0,01 & 0,01 \\
\hline 3 & 1 & 2 & 2 & 6 & 2,00 & 0,02 & 0,03 \\
\hline 2 & 1 & 1 & 1 & 2 & 1,00 & 0,01 & 0,01 \\
\hline 136 & 6 & 10 & 37 & 224 & 1,65 & $\mathbf{0 , 7 3}$ & 1,20 \\
\hline 4 & 2 & 2 & 3 & 4 & 1,00 & 0,02 & 0,02 \\
\hline 67 & 6 & 15 & 34 & 85 & 1,27 & 0,36 & 0,46 \\
\hline 10 & 3 & 6 & 8 & 16 & 1,60 & 0,05 & 0,09 \\
\hline 16 & 5 & 4 & 7 & 18 & 1,13 & 0,09 & 0,10 \\
\hline 3 & 2 & 3 & 3 & 3 & 1,00 & 0,02 & 0,02 \\
\hline 7 & 2 & 8 & 9 & 13 & 1,86 & 0,04 & 0,07 \\
\hline 2 & 1 & 1 & 1 & 2 & 1,00 & 0,01 & 0,01 \\
\hline 4 & 3 & 2 & 3 & 4 & 1,00 & 0,02 & 0,02 \\
\hline 2 & 1 & 1 & 1 & 2 & 1,00 & 0,01 & 0,01 \\
\hline 7 & 4 & 6 & 6 & 10 & 1,43 & 0,04 & 0,05 \\
\hline 10 & 4 & 4 & 6 & 15 & 1,50 & 0,05 & 0,08 \\
\hline 33 & 6 & 15 & 19 & 58 & 1,76 & 0,18 & 0,31 \\
\hline 7 & 2 & 4 & 4 & 8 & 1,14 & 0,04 & 0,04 \\
\hline 1 & 1 & 1 & 1 & 1 & 1,00 & 0,01 & 0,01 \\
\hline 1 & 1 & 1 & 1 & 1 & 1,00 & 0,01 & 0,01 \\
\hline 7 & 2 & 4 & 5 & 10 & 1,43 & 0,04 & 0,05 \\
\hline 12 & 5 & 9 & 10 & 21 & 1,75 & 0,06 & 0,11 \\
\hline 17 & 6 & 11 & 14 & 25 & 1,47 & 0,09 & 0,13 \\
\hline
\end{tabular}

Thonn. (Rubiaceae)

Gisekia pharmacioides L.

(Gisekiaceae)

Gladiolus gregarius L.

(Iridaceae)

Gossypium barbadense L.

(Malvaceae)

Gymnanthemum amygdalinum

(Delile) Sch. Bip ex Walp.

(Asteraceae)

Hallea stipulosa (DC.) Leroy

(Rubiaceae) 
Harungana madagascariensis

Lam ex Poir. (Hypericaceae)

Heinsia crinita (Afzel) G. Tayl.

(Rubiaceae)

Hibiscus acetosella Welw. ex

Hiern (Malvaceae)

Hymenocardia acida Tul.

(Phyllanthaceae)

Hymenocardia ulmoïdes Oliv.

(Phyllanthaceae)

Hyptis suaveolens Poit.

(Lamiaceae)

Indigofera paracapitata Gillett.

(Fabaceae)

Ipomoea batatas Poir

(Convolvulaceae)

Jatropha curcas L.

(Euphorbiaceae)

Justicia secunda Vahl.

(Acanthaceae)

Lagenaria brevifolia (Benth)

Roberty (Cucurbitaceae)

Lagenaria siceraria (Molina)

Standley (Cucurbitaceae)

Landolphia lanceolata (K.Schum)

M. Pichon (Apocynaceae)

Landolphia parvifolia (K. Schum)

(Apocynaceae)

\begin{tabular}{|c|c|c|c|c|c|c|c|}
\hline 38 & 6 & 8 & 16 & 52 & 1,37 & 0,20 & 0,28 \\
\hline 28 & 6 & 13 & 19 & 40 & 1,43 & 0,15 & 0,22 \\
\hline 4 & 1 & 2 & 2 & 4 & 1,00 & 0,02 & 0,02 \\
\hline 26 & 5 & 15 & 19 & 43 & 1,65 & 0,14 & 0,23 \\
\hline 13 & 4 & 9 & 10 & 20 & 1,54 & 0,07 & 0,11 \\
\hline 10 & 2 & 4 & 8 & 12 & 1,20 & 0,05 & 0,06 \\
\hline 78 & 5 & 2 & 19 & 80 & 1,03 & 0,42 & 0,43 \\
\hline 2 & 1 & 2 & 2 & 4 & 2,00 & 0,01 & 0,02 \\
\hline 25 & 5 & 15 & 19 & 29 & 1,16 & 0,13 & 0,16 \\
\hline 77 & 6 & 3 & 19 & 77 & 1,00 & 0,41 & 0,41 \\
\hline 2 & 1 & 1 & 1 & 2 & 1,00 & 0,01 & 0,01 \\
\hline 1 & 1 & 1 & 1 & 1 & 1,00 & 0,01 & 0,01 \\
\hline 6 & 2 & 4 & 5 & 7 & 1,17 & 0,03 & 0,04 \\
\hline 9 & 4 & 3 & 4 & 13 & 1,44 & 0,05 & 0,07 \\
\hline 4 & 2 & 2 & 2 & 4 & 1,00 & 0,02 & 0,02 \\
\hline 3 & 1 & 1 & 1 & 3 & 1,00 & 0,02 & 0,02 \\
\hline 2 & 2 & 2 & 2 & 2 & 1,00 & 0,01 & 0,01 \\
\hline 1 & 1 & 1 & 1 & 1 & 1,00 & 0,01 & 0,01 \\
\hline 7 & 2 & 2 & 3 & 7 & 1,00 & 0,04 & 0,04 \\
\hline 41 & 6 & 12 & 17 & 84 & 2,05 & 0,22 & 0,45 \\
\hline 4 & 2 & 2 & 2 & 4 & 1,00 & 0,02 & 0,02 \\
\hline 84 & 6 & 10 & 27 & 128 & 1,52 & 0,45 & 0,69 \\
\hline 40 & 6 & 12 & 31 & 74 & 1,85 & 0,22 & 0,40 \\
\hline 13 & 5 & 3 & 7 & 14 & 1,08 & 0,07 & 0,08 \\
\hline 4 & 2 & 1 & 2 & 4 & 1,00 & 0,02 & 0,02 \\
\hline
\end{tabular}

Lannea welwitschii (Hiern) Engl.

(Anacardiaceae)

Lantana camara L. (Verbenaceae)

Lasimorpha senegalensis Schott

(Araceae)

Leptoderris congolensis De Wild.

(Fabaceae)

Limnocharis flava (L.) Buchenan

(Butomaceae)

Lippia multiflora L.

(Verbenaceae)

Macaranga angolensis Müll.

Arg. (Euphorbiaceae)

Mangifera indica $\mathrm{L}$.

(Anacardiaceae)

Manihot esculenta Grantz

(Euphorbiaceae)

Maprounea africana Müll. Arg.

(Euphorbiaceae)

Markhamia tomentosa (Benth.) K.

Schum. (Bignoniaceae) 
Megaphrynium macrostachyum

(Benth) Milne-Redhead

(Marantaceae)

Micrococca mercurialis (L.)

Benth. (Euphorbiaceae)

Milicia excelsa (Welw.) C. Berg.

(Moraceae)

Millettia drastica Welw. ex Baker

(Fabaceae)

Millettia eetveldeana (Micheli)

Hauman (Fabaceae)

Millettia laurentii De Wild.

(Fabaceae)

Millettia versicolor Welw. ex

Baker (Fabaceae)

Mimosa pudica L. (Fabaceae)

Mitracarpus villosus (Sw.) DC.

(Rubiaceae)

Momordica charantia L.

(Cucurbitaceae)

Mondia whitei (Hook. F.)Stapf.

(Apocynaceae)

Monodora myristica (Gaertn)

Dunal (Annonaceae)

Morinda lucida Benth.

(Rubiaceae)

Morinda morindoides (Baker)

Melne. Redh. (Rubiaceae)

Moringa oleifera Lam.

(Moringaceae)

Musa paradisiaca L. (Musaceae)

Musa sp2 (Musaceae)

Musanga cecropiö̈des $\mathrm{R}$. Br.

(Cecropiaceae)

Nicotiana tabacum L.

(Solanaceae)

Nymphaea lotus L.

(Nymphaeaceae)

Ochna afzelii R.Br. (Ochnaceae)

Ocimum americanum $\mathrm{L}$.

(Lamiaceae)

Ocimum basilicum L.

(Lamiaceae)

Ocimum gratissimum $\mathrm{L}$.

(Lamiaceae)

Olax viridis Oliv. (Olacaceae)

Oncoba welwitschii (Oliv.)Gilg.

(Salicaceae)

Oryza sativa L. (Poaceae)

\begin{tabular}{|c|c|c|c|c|c|c|c|}
\hline 1 & 1 & 1 & 1 & 1 & 1,00 & 0,01 & 0,01 \\
\hline 7 & 4 & 2 & 4 & 7 & 1,00 & 0,04 & 0,04 \\
\hline 7 & 4 & 3 & 5 & 7 & 1,00 & 0,04 & 0,04 \\
\hline 6 & 4 & 5 & 5 & 8 & 1,33 & 0,03 & 0,04 \\
\hline 4 & 2 & 3 & 3 & 4 & 1,00 & 0,02 & 0,02 \\
\hline 1 & 1 & 2 & 2 & 2 & 2,00 & 0,01 & 0,01 \\
\hline 9 & 5 & 4 & 6 & 9 & 1,00 & 0,05 & 0,05 \\
\hline 4 & 1 & 2 & 2 & 8 & 2,00 & 0,02 & 0,04 \\
\hline 2 & 1 & 1 & 1 & 2 & 1,00 & 0,01 & 0,01 \\
\hline 3 & 2 & 3 & 4 & 7 & 2,33 & 0,02 & 0,04 \\
\hline 11 & 6 & 6 & 6 & 25 & 2,27 & 0,06 & 0,13 \\
\hline 29 & 6 & 10 & 17 & 40 & 1,38 & 0,16 & 0,22 \\
\hline 33 & 6 & 13 & 27 & 54 & 1,64 & 0,18 & 0,29 \\
\hline 138 & 6 & 24 & 35 & 294 & 2,13 & 0,74 & $\mathbf{1 , 5 8}$ \\
\hline 84 & 6 & 23 & 54 & 210 & 2,50 & 0,45 & 1,13 \\
\hline 4 & 1 & 4 & 4 & 6 & 1,50 & 0,02 & 0,03 \\
\hline 1 & 1 & 1 & 1 & 1 & 1,00 & 0,01 & 0,01 \\
\hline 2 & 1 & 1 & 1 & 2 & 1,00 & 0,01 & 0,01 \\
\hline 3 & 2 & 3 & 4 & 6 & 2,00 & 0,02 & 0,03 \\
\hline 2 & 2 & 1 & 1 & 2 & 1,00 & 0,01 & 0,01 \\
\hline 41 & 5 & 3 & 10 & 42 & 1,02 & 0,22 & 0,23 \\
\hline 104 & 6 & 16 & 39 & 174 & 1,67 & 0,56 & 0,94 \\
\hline 3 & 2 & 2 & 2 & 3 & 1,00 & 0,02 & 0,02 \\
\hline 145 & 6 & 13 & 43 & 229 & 1,58 & 0,78 & 1,23 \\
\hline 4 & 2 & 4 & 4 & 5 & 1,25 & 0,02 & 0,03 \\
\hline 8 & 4 & 7 & 7 & 10 & 1,25 & 0,04 & 0,05 \\
\hline 4 & 2 & 1 & 2 & 4 & 1,00 & 0,02 & 0,02 \\
\hline
\end{tabular}


Pachira glabra (Pasquale) A.

Robyns (Malvaceae)

Palisota ambigua (P. Beauv.)

(Commelinaceae)

Parinari capensis Harv.

(Chrysobalanaceae)

Paropsia brazzeana Baill.

(Passifloraceae)

Pauridiantha dewevrei (De Wild.

$\&$ Th. Dr. (Rubiaceae)

Pentaclethra macrophylla Benth.

(Fabaceae)

Pentadiplandra brazzeana Baill.

(Pentadiplandraceae)

Persea americana Mill.

(Lauraceae)

Piper nigrum L. (Piperaceae)

Psidium guajava L. (Myrtaceae)

Psophocarpus scandens (Endl.)

Verdc. (Fabaceae)

Psorospermum febrifugum Spath.

(Hypericaceae)

Pteridium aquilinium L.

(Hypolepidaceae)

Quassia africana (Baill.) Baill.

(Simaroubaceae)

\begin{tabular}{|c|c|c|c|c|c|c|c|}
\hline 1 & 1 & 1 & 1 & 1 & 1,00 & 0,01 & 0,01 \\
\hline 2 & 1 & 1 & 1 & 2 & 1,00 & 0,01 & 0,01 \\
\hline 11 & 3 & 3 & 5 & 12 & 1,09 & 0,06 & 0,06 \\
\hline 6 & 2 & 4 & 4 & 7 & 1,17 & 0,03 & 0,04 \\
\hline 1 & 1 & 2 & 2 & 2 & 2,00 & 0,01 & 0,01 \\
\hline 4 & 2 & 2 & 2 & 4 & 1,00 & 0,02 & 0,02 \\
\hline 93 & 6 & 11 & 28 & 170 & 1,83 & $\mathbf{0 , 5 0}$ & 0,91 \\
\hline 114 & 6 & 8 & 43 & 129 & 1,13 & 0,61 & 0,69 \\
\hline 22 & 5 & 6 & 14 & 32 & 1,45 & 0,12 & 0,17 \\
\hline 39 & 6 & 4 & 13 & 45 & 1,15 & 0,21 & 0,24 \\
\hline 8 & 2 & 5 & 6 & 11 & 1,38 & 0,04 & 0,06 \\
\hline 17 & 4 & 3 & 9 & 19 & 1,12 & 0,09 & 0,10 \\
\hline 6 & 3 & 2 & 3 & 6 & 1,00 & 0,03 & 0,03 \\
\hline 6 & 3 & 13 & 18 & 29 & 4,83 & 0,03 & 0,16 \\
\hline 2 & 1 & 2 & 2 & 2 & 1,00 & 0,01 & 0,01 \\
\hline 2 & 2 & 4 & 4 & 4 & 2,00 & 0,01 & 0,02 \\
\hline 62 & 6 & 6 & 11 & 78 & 1,27 & 0,32 & 0,41 \\
\hline 2 & 1 & 1 & 1 & 2 & 1,00 & 0,01 & 0,01 \\
\hline 2 & 1 & 2 & 2 & 4 & 2,00 & 0,01 & 0,02 \\
\hline 25 & 6 & 7 & 12 & 26 & 1,04 & 0,13 & 0,14 \\
\hline 27 & 5 & 3 & 7 & 28 & 1,04 & 0,15 & 0,15 \\
\hline 1 & 1 & 1 & 1 & 1 & 1,00 & 0,01 & 0,01 \\
\hline 99 & 6 & 14 & 29 & 139 & 1,40 & $\mathbf{0 , 5 3}$ & 0,75 \\
\hline 133 & 6 & 9 & 34 & 167 & 1,26 & 0,72 & 0,90 \\
\hline 1 & 1 & 1 & 1 & 1 & 1,00 & 0,01 & 0,01 \\
\hline 32 & 5 & 8 & 11 & 39 & 1,22 & 0,17 & 0,21 \\
\hline
\end{tabular}

Raphia textilis Welw. (Arecaceae)

Rhabdophyllum arnoldianum (De

Wild \& T. Durand) (Ochnaceae)

Saccharum officinarum $\mathrm{L}$.

(Poaceae)

Salacia pynaertii De Wild.

(Celastraceae)

Sanseviera trifasciata Train

(Asparagaceae)

Schwenckia americana L.

(Solanaceae)

Sclerocroton cornutus (Pax) Krujt

$\&$ Roebers. (Euphorbiaceae)

Scoparia dulcis L.

(Scrophulariaceae)

Securidaca longepedunculata

Fresen (Polygalaceae)

Senna occidentalis (L.) Link

(Fabaceae)

Sesamum orientale L.

(Pedaliaceae)

Sesamum radiatum Schumach \&

Thonn. (Pedaliaceae) 
Sida cordifolia L. (Malvaceae)

Solanum aethiopicum L.

(Solanaceae)

Solanum lycopersicum Mill.

(Solanaceae)

Solanum macrocarpon L.

(Solanaceae)

Sterculia tragacantha Lindl.

(Malvaceae)

Stomatatens africanus (Oliv. et

Hirn) R.H. King. (Asteraceae)

Strychnos cocculoides Baker

(Loganiaceae)

Strychnos icaja L. (Loganiaceae)

Strychnos pungens Soler.

(Loganiaceae)

Strychnos spinosa Lam.

(Loganiaceae)

Syzygium guineense (Wild.) DC.

(Myrtaceae)

Syzygium malaccense (L.) Merr.

(Myrtaceae)

Talinum fructicosum (L.) A. Juss.

(Talinaceae)

Tephrosia lupinifolia DC.

(Fabaceae)

Tephrosia vogelii Hook.f.

(Fabaceae)

Treculia africana Decne

(Moraceae)

Triclisia dyctyophilla Diels.

(Menispermaceae)

Tridax procumbens $\mathrm{L}$.

(Asteraceae)

Urena lobata L. (Malvaceae)

Vernonia potamophila Klatt

(Asteraceae)

Vigna unguiculata (L.) Walp.

(Fabaceae)

Vitex madiensis Oliv. (Lamiaceae)

Voacanga africana Stapf.

(Apocynaceae)

Xylopia aethiopica (Dunal) A.

Rich. (Annonaceae)

Zea mays L. (Poaceae)

Zingiber officinale Roscoe

(Zingiberaceae)

\begin{tabular}{|c|c|c|c|c|c|c|c|}
\hline 3 & 2 & 2 & 2 & 3 & 1,00 & 0,02 & 0,02 \\
\hline 4 & 3 & 3 & 4 & 8 & 2,00 & 0,02 & 0,04 \\
\hline 32 & 6 & 9 & 16 & 47 & 1,47 & 0,17 & 0,25 \\
\hline 3 & 2 & 1 & 1 & 3 & 1,00 & 0,02 & 0,02 \\
\hline 3 & 2 & 2 & 2 & 3 & 1,00 & 0,02 & 0,02 \\
\hline 2 & 2 & 3 & 4 & 4 & 2,00 & 0,01 & 0,02 \\
\hline 39 & 6 & 4 & 14 & 44 & 1,13 & 0,21 & 0,24 \\
\hline 17 & 6 & 8 & 13 & 36 & 2,12 & 0,09 & 0,19 \\
\hline 2 & 2 & 3 & 3 & 3 & 1,50 & 0,01 & 0,02 \\
\hline 4 & 2 & 2 & 2 & 4 & 1,00 & 0,02 & 0,02 \\
\hline 5 & 2 & 2 & 3 & 5 & 1,00 & 0,03 & 0,03 \\
\hline 1 & 1 & 2 & 2 & 2 & 2,00 & 0,01 & 0,01 \\
\hline 3 & 1 & 1 & 1 & 3 & 1,00 & 0,02 & 0,02 \\
\hline 4 & 3 & 5 & 6 & 6 & 1,50 & 0,02 & 0,03 \\
\hline 2 & 1 & 1 & 1 & 2 & 1,00 & 0,01 & 0,01 \\
\hline 2 & 1 & 1 & 1 & 2 & 1,00 & 0,01 & 0,01 \\
\hline 4 & 2 & 1 & 1 & 4 & 1,00 & 0,02 & 0,02 \\
\hline 14 & 4 & 5 & 9 & 20 & 1,43 & 0,08 & 0,11 \\
\hline 25 & 6 & 7 & 19 & 37 & 1,48 & 0,13 & 0,20 \\
\hline 71 & 6 & 9 & 18 & 88 & 1,24 & 0,38 & 0,47 \\
\hline 1 & 1 & 1 & 1 & 1 & 1,00 & 0,01 & 0,01 \\
\hline 32 & 5 & 10 & 19 & 47 & 1,47 & 0,17 & 0,25 \\
\hline 1 & 1 & 1 & 1 & 1 & 1,00 & 0,01 & 0,01 \\
\hline 61 & 0 & 14 & 37 & 85 & 1,39 & 0,33 & 0,46 \\
\hline 1 & 1 & 1 & 1 & 1 & 1,00 & 0,01 & 0,01 \\
\hline 16 & 6 & 7 & 13 & 22 & 1,38 & 0,09 & 0,1 \\
\hline
\end{tabular}


Table 4: List of indications types treated by medicinal plants (Nber de cu: number of citation and \%: percentage)

\begin{tabular}{|c|c|c|}
\hline Indications & Nber cu & $\%$ \\
\hline Abscess & 32 & 0,58 \\
\hline Abdominal pain & 2 & 0,04 \\
\hline Against abortion & 9 & 0,16 \\
\hline Against evil espirits & 9 & 0,16 \\
\hline Against incurable diseases & 1 & 0,02 \\
\hline Against lightning & 6 & 0,11 \\
\hline Against the night husband & 2 & 0,04 \\
\hline Against the rain & 10 & 0,18 \\
\hline Against the serpent & 5 & 0,09 \\
\hline Against wizards & 11 & 0,20 \\
\hline Agalactia & 1 & 0,02 \\
\hline Halicire & 63 & 1,14 \\
\hline Amoebic dysentery & 2 & 0,04 \\
\hline anemia & 651 & 11,81 \\
\hline Angina & 5 & 0,09 \\
\hline Ankylomiasis & 6 & 0,11 \\
\hline Antiphlogistic & 10 & 0,18 \\
\hline Aperitif & 15 & 0,27 \\
\hline Appendicitis & 13 & 0,24 \\
\hline Aprodisiac & 10 & 0,18 \\
\hline Ascariasis & 2 & 0,04 \\
\hline Ascites & 32 & 0,58 \\
\hline Asthma & 33 & 0,60 \\
\hline Backache & 241 & 4,37 \\
\hline Belly ringing & 2 & 0,04 \\
\hline Bronchitis & 14 & 0,25 \\
\hline Bug the stomach & 49 & 0,89 \\
\hline Burn & 5 & 0,09 \\
\hline Cardiopathy & 17 & 0,31 \\
\hline Cataract & 13 & 0,24 \\
\hline Chickenpox & 43 & 0,78 \\
\hline Chronic gastritis & 93 & 1,69 \\
\hline Chronic rhinitis & 61 & 1,11 \\
\hline Colic & 8 & 0,15 \\
\hline Complications of pregnancy & 6 & 0,11 \\
\hline Confusion in children & 1 & 0,02 \\
\hline
\end{tabular}


Congestion of the lungs

Conjonctivitis

Constipation

Continual fever

Cough

Cries in the child

Deafness

Dehydrated

Dental caries

Diabetes

Diarrhea

Disinfectant

Dizzy spells

Drunkenness

Dysmenorrhoea

Dystocia

Ear sores

Earache

Elephantiasis

Epilepsy

Eye disease

Facial paralysis

Fainting fit

Fever

Filariosis

Flu

Fracture

General infection

General pain

Genital infection in woman

Geography legs

Gonorrhoea

Gonorrhoea infection

Headache

Headaches in children

Healing wounds

Hearing fond

Heart attack

$\begin{array}{ll}2 & 0,04 \\ 3 & 0,05 \\ 3 & 0,05 \\ 1 & 0,02\end{array}$

628

11,39

$6 \quad 0,11$

$1 \quad 0,02$

73

1,32

75

1,36

31

0,56

125

2,27

2

0,04

$2 \quad 0,04$

$3 \quad 0,05$

$9 \quad 0,16$

$3 \quad 0,05$

$4 \quad 0,07$

$22 \quad 0,40$

$19 \quad 0,34$

$40 \quad 0,73$

$3 \quad 0,05$

$7 \quad 0,13$

20,04

566110,27

$8 \quad 0,15$

$62 \quad 1,12$

$2 \quad 0,04$

$1 \quad 0,02$

$290 \quad 5,26$

$1 \quad 0,02$

$3 \quad 0,05$

$3 \quad 0,05$

$1 \quad 0,02$

$158 \quad \mathbf{2 , 8 7}$

$1 \quad 0,02$

$2 \quad 0,04$

$3 \quad 0,05$

$3 \quad 0,05$ 
Hemorrhoids

Hepatitis

Hernia

Hiccups

High blood pressure

Hypogalactia

Infertility in woman

Insecticide

Kwashiorkor

Language

Layer suites

Leg pain

Loss of weight

Low blood pressure

Lumbago

Madness

Malaria

Malnutrition

Measles

Meningitis

Microbial infection

Mumps

Mycosis

Neck

Non-suppurative otitis media

Nutritional athrepsy

Odontalgia

Ophtalmia

Otalgia

Otitis externa

Pain after childbirth

Poliomyelitis

Poor-quality

Prostate

Psychic trouble

Purgative

Rash

Remains
177

3,21

0,07

0,11

6

0,04

17

0,31

3

0,05

4

0,07

13

0,24

7

0,13

$1 \quad 0,02$

28

0,51

11

0,20

3

0,05

13

0,24

1

0,02

4

0,07

221

$\mathbf{4 , 0 1}$

4

0,07

73

1,32

11

0,20

3

0,05

1

0,02

18

0,33

6

0,11

4

0,07

2

0,04

1

0,02

7

0,13

3

0,02

0,05

2

0,04

8

0,15

8

0,15

2

0,04

14

0,25

2

0,04

22

0,40

1

0,02 


\begin{tabular}{|c|c|c|}
\hline Rheumatism & 24 & 0,44 \\
\hline Ringworm & 10 & 0,18 \\
\hline Scabies & 48 & 0,87 \\
\hline Sexual impotence & 11 & 0,20 \\
\hline Sinusitis & 8 & 0,15 \\
\hline Smallpox & 30 & 0,54 \\
\hline Smell & 1 & 0,02 \\
\hline Sore throat & 15 & 0,27 \\
\hline Sores in the baby's mouth & 1 & 0,02 \\
\hline Spleen disorders & 344 & 6,24 \\
\hline Sprain & 20 & 0,36 \\
\hline Stomach aches & 421 & 7,64 \\
\hline Stomach pain & 9 & 0,16 \\
\hline Stomatitis & 2 & 0,04 \\
\hline Testicle & 13 & 0,24 \\
\hline Tetanus & 4 & 0,07 \\
\hline To facilitate the conception of the child & 6 & 0,11 \\
\hline To facilitate walking in children & 42 & 0,76 \\
\hline To promote divorce & 1 & 0,02 \\
\hline To promote domination & 8 & 0,15 \\
\hline To promote memory & 1 & 0,02 \\
\hline To promote the fight & 4 & 0,07 \\
\hline Tonic & 6 & 0,11 \\
\hline Traumatism & 2 & 0,04 \\
\hline Typhoid fever & 4 & 0,07 \\
\hline Udder sores & 2 & 0,04 \\
\hline Unspecified site urinary tract infection & 3 & 0,05 \\
\hline washing of hair & 2 & 0,04 \\
\hline Water purification & 1 & 0,02 \\
\hline Whitlow & 11 & 0,20 \\
\hline Whooping cough & 2 & 0,04 \\
\hline Wound & 33 & 0,60 \\
\hline Wound with pain & 2 & 0,04 \\
\hline Yellow fever (Jaundice) & 63 & 1,14 \\
\hline General total & 5513 & 100,00 \\
\hline
\end{tabular}

